\title{
The impact of postglacial palaeoenvironmental changes on the properties of sediments in the kettle hole at Jurki (NE Poland)
}

\author{
Tomasz M. KARASIEWICZ ${ }^{1, ~ *, ~ P i o t r ~ H U L I S Z ~}{ }^{1}$, Agnieszka M. NORYŚKIEWICZ², \\ Renata STACHOWICZ-RYBKA ${ }^{3}$, Adam MICHALSKI ${ }^{1}$, Michał DARROWSKI ${ }^{1}$ and Wojciech W. GAMRAT ${ }^{1}$ \\ 1 Nicolaus Copernicus University, Faculty of Earth Sciences, Lwowska 1, 87-100 Toruń, Poland \\ 2 Nicolaus Copernicus University, Institute of Archaeology, Faculty of History, Szosa Bydgoska 44/48, 87-100 Toruń, \\ Poland, \\ 3 Polish Academy of Sciences, Władysław Szafer Institute of Botany, Lubicz 46, 31-512 Kraków, Poland
}

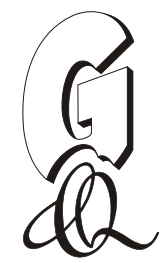

Karasiewicz, M.T., Hulisz, P., Noryśkiewicz, A.M., Stachowicz-Rybka, R., Michalski, A., Dabrowski, M., Gamrat, W.W., 2017. The impact of postglacial palaeoenvironmental changes on the properties of sediments in the kettle hole at the site of Jurki (NE Poland). Geological Quarterly, 61 (2): 319-333, doi: 10.7306/gq.1346

This research is focused on a small kettle hole located within the Morag moraines (Iława Lake District, NE Poland). The study objective was to determine the impact of palaeoenvironmental changes on properties of sediments filling the bottom of the kettle hole. Sedimentological, geochemical, and palaeobotanical studies enabled us to distinguish several development phases of the kettle hole, and cluster analysis performed on physicochemical data yielded seven local geochemical zones $\left(\mathrm{Ju}_{/ / 1}\right.$ to $\left.\mathrm{Ju} / / \mathrm{VII}\right)$. The beginning of biogenic sedimentation in the conditions of a small water body, functioning in the Late Glacial period $(4.20-4.10 \mathrm{~m})$, was determined on the basis of palaeobotanical research. Sediments deposited in the lake during its further evolution were rich in microelements such as $\mathrm{Ca}, \mathrm{Na}, \mathrm{Mg}$, and $\mathrm{K}$, and to a smaller extent - $\mathrm{Fe}$ and $\mathrm{Mn}$ ( $\mathrm{Ju} / / / I I I I$ local geochemical zones). The Late Glacial lacustrine period ended with the accumulation of very silty, pollen-free gyttja, with a stratigraphic hiatus $\left(\mathrm{Ju}_{\mathrm{IIV}}, 3.40-3.20 \mathrm{~m}\right)$. The sediments were enriched with $\mathrm{SiO}_{2 \text { ter, }}$ which indicates an increased rate of slope erosion, and concretions of $\mathrm{Fe}-\mathrm{Mn}$ occurring below this layer $\left(\mathrm{Ju}_{\mathrm{III}}\right)$ provide evidence for lowering of the water level and even desiccation. In the Holocene, the lacustrine period ended with the accumulation of coarse detrital gyttja $(3.20-2.60 \mathrm{~m})$ Palaeobotanical data indicate that the next group of sediments were deposited in the Late Subboreal and Subatlantic periods $(2.60-0.0 \mathrm{~cm}, \mathrm{Ju} / \mathrm{V}-\mathrm{VII} ;$; sedge peat). Their properties were varied and related to hydrologic conditions, limited denudation, and vegetation succession. There was also a significant change in the trophic conditions of the water and consequently in the sediments of the kettle hole, which changed during the lacustrine period from basic to acid, and strongly acid in the surface layer. This reaction may be related to a change in the water regime as well as to human impact in the environment, which led to the colonization of the peat bog by Sphagnum moss.

Key words: young glacial landscape, kettle hole, end moraines, geochemical analysis, biogenic deposits.

\section{INTRODUCTION}

Kettle holes are a common feature of a young glacial landscape. They are defined as small, shallow, depressional wetlands of glacial origin with water supply coming from closed catchments (Kalettka and Rudat, 2006). As isolated depressions with vertical water fluctuation, they are usually very sensitive to both natural and anthropogenic environmental changes (e.g., Küster et al., 2011). Therefore, analysis of sediments deposited at their bottoms is often a key element in the reconstruction of e.g., palaeoclimatic, palaeohydrological, palaeobotanical and sometimes archaeological conditions.

\footnotetext{
* Corresponding author, e-mail: mtkar@umk.pl

Received: March 11, 2016; accepted: July 13, 2016; first published online: March 2, 2017
}

The functioning of these landforms may be strongly linked to regional or local settings and therefore large-scale changes associated with climate and hydrological conditions may affect their ecological integrity (Drexler et al., 1999; Fraser et al., 2001). The most important effects of such changes may include changes in the deposition/sedentation of sediments, fluctuations in water levels and increased peat decomposition (Gorham and Rochefort, 2003; Lamentowicz et al., 2008; Karasiewicz et al., 2014b; Forysiak, 2015).

Kettle holes are typically located in agricultural areas (Kochanowska et al., 1998; Karasiewicz et al., 2014a; Kleeberg et al., 2015). According to Kalletka and Rudat (2006), there are two main hydrogeomorphic types of these forms: fen type (with growing fen) and open-water type (permanently or temporarily flooded, filled with peat and non-peat sediments).

Many authors (e.g., Frielinghaus and Vahrson, 1998; Podlasiński, 2013; Świtoniak, 2014; Karasiewicz et al., 2014b) stress that, due to long-term agricultural use, the catchment area is prone to accelerated soil erosion by runoff. Consequently, kettle holes may receive abundant terrigenous material 
from adjacent slopes, which may lead to their disappearance and levelling of the land relief. Their sediments can act as sinks for nutrients ( $\mathrm{N}, \mathrm{P}$ and $\mathrm{K}$ ), pesticides, and heavy metals, and consequently as a geochemical barrier which reduces the spread of pollutants (Cooper and Knight, 1990; Bilotta et al., 2007; Podlasińska, 2012).

Kettle holes in Poland are still relatively rarely included in palaeoenvironmental studies. This is due to the widespread belief that their sediments reflect only local changes in the environment, and hence the obtained results might be of limited use. The examples presented below, however, prove the contrary. Comprehensive palaeogeographic studies involving geochemical analyses were conducted by Borówka (1992) on sediments collected from small kettle holes in Western Pomerania. Similar studies carried out by Major (2009) concern the functioning of kettle holes in the drainage basin of the upper Parsęta River. Szwarczewski (2008) and Szwarczewski and Kupryjanowicz (2008) described the development stages of kettle holes in the Eastern Suwałki Lake District near the town of Sejny based on the properties of their sediments. Interdisciplinary studies of sediments of single landforms were conducted in the Brodnica Lake District (Karasiewicz et al., 2012, 2014b; Mendyk et al., 2015), and in the neighbourhood of Łódź (Lamentowicz et al., 2009; Twardy et al., 2010). There are also examples of research on geomorphological processes connected with environmental changes during the Late Pleistocene and the Holocene in the mountain areas (e.g., Jäger et al., 2015; Malkiewicz et al., 2016). A common objective of these studies was to reconstruct the palaeoenvironmental conditions recorded in sediments, which were treated as archives and carriers of information. The authors obtained good correlations between local and regional palaeogeographic changes. An example of a different approach was studies in the field of palaeoecology that analyse the man-induced transformations of the environment in the Tuchola Forest (Lamentowicz et al., 2007, 2008). The research on kettle holes may also be helpful in determining the chronostratigraphy of geomorphological events in river valleys. The results obtained by Krześlak et al. (2014) link the beginning of lacustrine sedimentation in the kettle hole located within terrace $\mathrm{V}$ of the Vistula Valley (Toruń Basin) with the formation of lower terraces in the Late Glacial period.

The research presented in this paper focuses on the kettle hole functioning in the agricultural landscape of the lława Lake District in the area of Morag moraines (Jurki site, NE Poland). This study aims to analyse the effect of palaeoenvironmental changes on the sedimentological and geochemical properties of kettle hole sediments. Based on the results obtained, combined with palaeobotanical and radiocarbon data, the local palaeoenvironment and the human impact on some of the landscape components were determined. This is a continuation of the multi-proxy studies focusing on kettle holes of different genesis and different land use, located near the main stagnation lines of the Vistulian ice sheet (Karasiewicz et al., 2014a, b).

\section{STUDY AREA}

The kettle hole studied in the Jurki village is of a small form (bottom $-40 \times 60 \mathrm{~m}$, the direct catchment area $-4.6 \mathrm{ha}$ ). It is located ca. $4 \mathrm{~km}$ north of Morag $\left(53^{\circ} 58^{\prime} \mathrm{N}\right.$ and $19^{\circ} 58^{\prime} \mathrm{E}$; the llawa Lake District, NE Poland; Fig. 1). The site is located at the southern side (distal part) of the recessional end moraines from the Pomeranian Phase of the Vistulian Glaciation, the height of which locally exceeds 200 m a.s.l. (Roszkówna, 1955; Karasiewicz, 2006a, b). The moraines form a belt extending from east to west with a width ranging from 2 to $4.5 \mathrm{~km}$. Roszkówna (1955) distinguished three zones within the belt: the internal (till) zone, the central zone (built of glacial sand and fluvioglacial deposits), and the outer (pushed) zone. The interior of the frontal moraines is built up of pushed fluvioglacial deposits, locally with till on the surface. The research by Karasiewicz (2006a, b) revealed that the internal structure of the Morag moraines is glaciotectonically disturbed, and the arrangement of moraine belts is connected with lobal-oscillatory disappearance of the continental ice sheet in this zone. It is difficult to determine the southern (outer) range of the Morag moraines, which often smoothly turn into a hilly moraine plateau (Karasiewicz, 2006a, b).

The origin of the kettle hole studied is most likely connected with the melting of a dead-ice block in moraine deposits, hence the surroundings and substratum of this landform is dominated by deposits of sand, gravel, and boulders of end moraines. Colluvial deposits are found in the lower parts of the slopes, while the bottom of the kettle hole is filled with biogenic sediments. In the past, the entire direct catchment of the kettle hole studied was used for agriculture, while at present, land use is varied. Young stands of oak and spruce trees occur along the northern and eastern edges of the depression: arable fields in the south, and meadows and pastures in the west. The bottom of the kettle hole is overgrown with shrubs and birch and willow trees. The groundcover is dominated by Sphagnum peat, moss peat and sedges.

\section{METHODS}

Sampling. In total, 18 boreholes were drilled within the direct drainage basin and in the bottom of the kettle hole in the Jurki village. Based on the boreholes, 3 cores with an intact structure were collected by a Livingstone's probe modified by Więckowski (1989) in the central $\left(\mathrm{Ju}_{1}\right)$, northern $\left(\mathrm{Ju}_{\|}\right)$, and southern $\left(\mathrm{Ju}_{\| I I}\right)$ parts of the depression (Fig. 1$)$. In addition, 4 soil pits were made on the slopes of the kettle hole. Their location closely corresponded with the two main types of land use in the drainage basin: agricultural (profiles $A$ and $B$ ) and forest (profiles $C$ and $D$ ). The samples were analysed using the selected sedimentological, geochemical, and palaeobotanical methods described below.

\section{SEDIMENTOLOGICAL AND GEOCHEMICAL ANALYSIS}

Grain-size composition. Samples collected from the slope sediments (profiles A-D, 42 samples) were dried and sieved using a set of sieves with diameters ranging from 10 to $0.1 \mathrm{~mm}$. The finer fraction was determined using a Fritsch laser particle sizer Analysette 22. For each sample, textural parameters such as mean diameter $(\mathrm{Mz})$ and sorting $\left(\sigma_{1}\right)$ were calculated according to Folk and Ward (1957) - Gradistat software (Blott and Pye, 2001).

Geochemistry. Analyses were performed on samples collected from two cores, which reflected the differentiation of the sediment sequence i.e. from the central part of the kettle hole ( $\mathrm{Ju}_{1}$ - thickness of $4.20 \mathrm{~m} ; 55$ samples) and from its southern peripheries ( $\mathrm{Ju} \| \mid-1.70 \mathrm{~m} ; 33$ samples), as well as from two outcrops on the slopes (profile A-1.50 m; and D-1.40 m: 22 samples). The following parameters were determined in the biogenic and mineral deposits

- the content of organic matter loss on ignition at a temperature of $550^{\circ} \mathrm{C}$ for $3 \mathrm{~h}$

- reaction $(\mathrm{pH})$ by the potentiometric method;

- the content of calcium carbonate by Scheibler's method. 


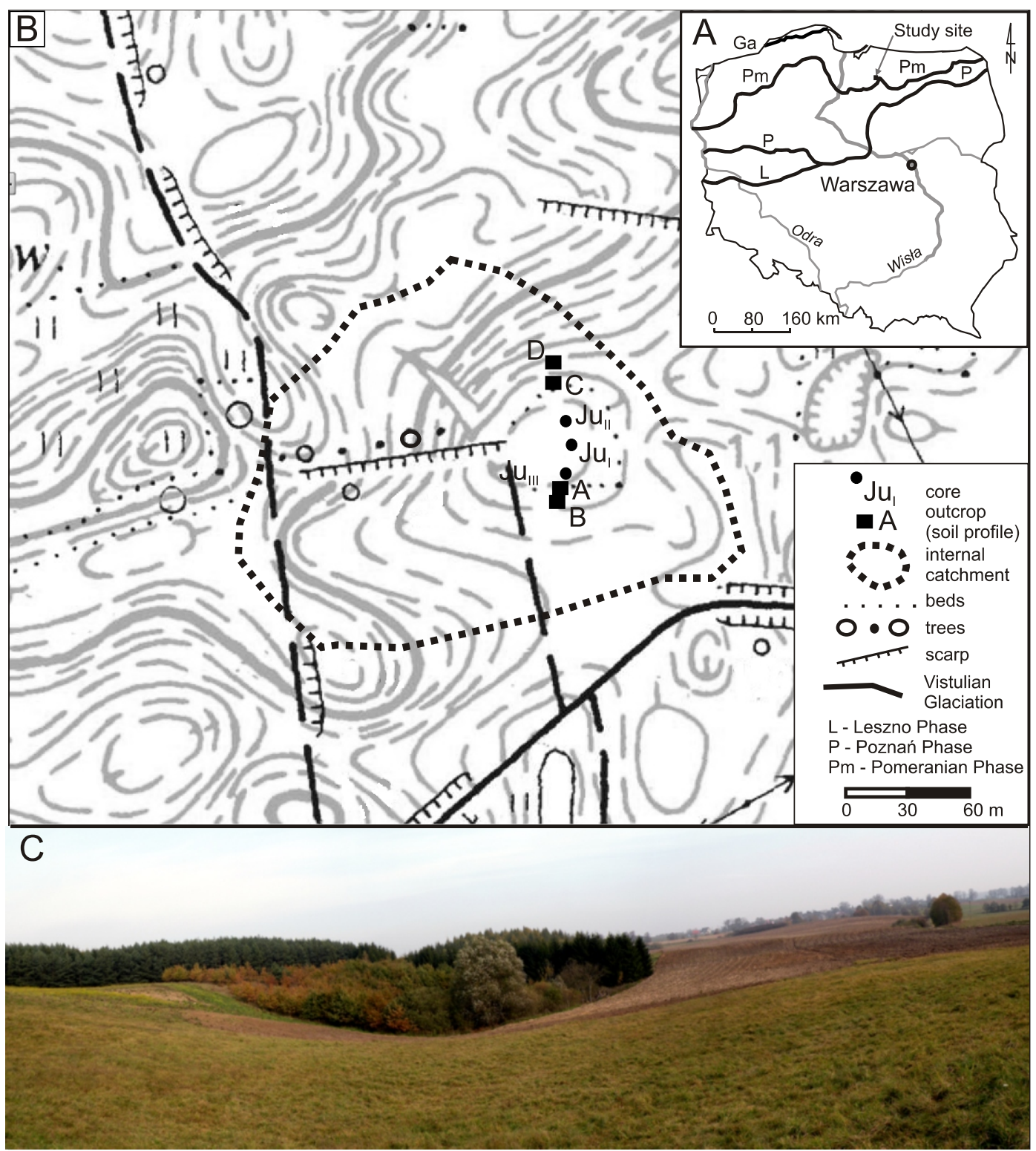

Fig. 1. Map of the study area

A - location related to the extent of the Vistula Glaciation, of the Pomeranian Phase in Poland; B - detailed location on a topographic map; C - view of the kettle hole studied from the west

The total content of $\mathrm{Ca}, \mathrm{Mg}, \mathrm{Fe}$, and $\mathrm{Mn}$ was determined by atomic absorption spectrometry (AAS); $\mathrm{Na}$ and $\mathrm{K}$ content was determined by emission spectrometry (ES) after treatment of samples with $\mathrm{HNO}_{3}+\mathrm{H}_{2} \mathrm{O}_{2}$ mixture on a sand bath. The content of terrigenous silica was determined in the sediments of core $\mathrm{Ju}_{\mathrm{I}}$ and $\mathrm{Ju}_{\| I \mid}$ using a method proposed by Apolinarska et al. (2012) - by digestion of samples using aqua regia and $\mathrm{NaOH}$ after ignition at $550^{\circ} \mathrm{C}$.

Statistical analysis (Ju, core only). Hierarchical cluster analysis was used to identify the geochemical zones (Past software). The software package Statistica 9.0 (Statsoft Inc.) was used to draw scatter plots between selected parameters of the sediments.
PALAEOBOTANICAL ANALYSES

Pollen analysis. A total of 72 sediment samples $\left(\mathrm{Ju}_{1}-45\right.$ samples and $\mathrm{Ju}_{\| I}-27$ samples) of $1 \mathrm{~cm}^{3}$ volume at a resolution of $5-10 \mathrm{~cm}$ were examined palynologically, and based on the standard procedures were treated with $10 \% \mathrm{HCl}, 10 \% \mathrm{KOH}$, $40 \% \mathrm{HF}$, and Erdtman's acetolysis (Berglund and Ralska-Jasiewiczowa, 1986). A known number of indicator spores of Lycopodium (Stockmarr, 1971) was added to each sample in order to determine pollen concentration. The Polpal software for Windows (Nalepka and Walanus, 2003) was used to analyse the results. 
Macroremain analysis. A total of 43 sediment samples (10 samples from the bottom of the profile did not contain plant macroremains) were collected in close correlation with palynological sampling $(\mathrm{Ju}, \mathrm{core})$. They were taken at the following intervals: every 5 or $10 \mathrm{~cm}$ (depending on the lithological characteristics) along the remaining $3.25 \mathrm{~m}$ up to the topmost layer. The samples were macerated according to a standard procedure (adopted by e.g., Stachowicz-Rybka, 2011).

Radiocarbon dating. One bulk sample from the $\mathrm{Ju}$, core ( $0.25 \mathrm{~m}$ b.g.l.) was dated. The analysis was carried out at the Radiocarbon Laboratory, the Silesian University of Technology in Gliwice (Poland). The data were calibrated using the OxCal v. 4.2.2 software (Bronk Ramesy, 2009).

\section{RESULTS}

Lithology and chronology. Based on the field research conducted on the sediments of the direct catchment of the kettle hole studied, it was found that sand, gravel, and boulders of end moraines dominate in the substrate, often interbedded with flow till of a small thickness. On the other hand, the thickness of colluvial deposits and tillage diamicton (agricultural colluvia) increased towards the bottom of the depression. Those were mainly sand deposits, with an addition of ca. $10 \%$ of silt. The fraction of gravel and clay accounted for a total of up to $10 \%$. The median (Mz) for deposits of profile A ranged from 1.53 to 4.08 phi; the mean was 2.35 (Figs. 2 and 3). Similar results were obtained for other profiles ( $\mathrm{Mz}$ from 2 to 3 phi). The sediments analysed were poorly sorted $\left(\sigma_{1} 1.42-2.94\right)$ and differed from each other in colour and enrichment with organic matter. Buried soil horizons were identified in profile $A$ at depths of $0.80-0.90 \mathrm{~m}$ and $1.10-1.20 \mathrm{~m}$ (Fig. 3). The thickness of colluvial deposits in the profiles analysed (A-D, Fig. 2) was $>0.80 \mathrm{~m}$, and the maximum was $1.30 \mathrm{~m}$. In the case of slopes with northern (profile A) and southern (profile C) exposure, the deposits are easily identified because they cover the biogenic sediments (peat). Despite the fact that all soils represented by profiles A-D were developed from slope sediments, their properties differed markedly. Therefore, they were classified into various soil units according to WRB system (IUSS Working Group WRB, 2015), i.e.: acidic soils having a umbric horizon (profiles $A$ and $C$ ) as Haplic Umbrisols (Colluvic), soils more rich in base cations with mollic horizon (profile B) as Haplic Phaeozems (Colluvic), and others (profile D) as Colluvic Regosols (Figs. 2 and 3).

Mineral-organic gyttja was found at the floor (bottom) of the kettle hole, covered with sedge and moss peat (Dystric Histosols; Fig. 2). The maximum thickness of organic sediments was determined in the central part of the kettle hole $4.15 \mathrm{~m}\left(\mathrm{Ju}_{\mathrm{l}}\right)$. In the second core $\left(\mathrm{Ju}_{\|}\right)$, located several metres away from the first one to the south-east, biogenic sediments had a thickness of $3.56 \mathrm{~m}$. Biogenic sediments in the third core $\left(\mathrm{Ju}_{\| 1}\right.$; located at the southern edge of the bottom) had a thickness of only $1.20 \mathrm{~m}$ and occurred in the form of peat with a high content of mineral matter (Fig. 2).

The stratigraphy of the sediment sequence in the kettle hole studied was based on the palynological analysis performed in

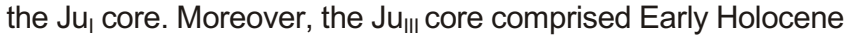
deposits (Fig. 4). The seven local pollen zones were distinguished (L PAZ - local pollen assemblage zones; Fig. 4). They related to the development of vegetation in north-central Poland

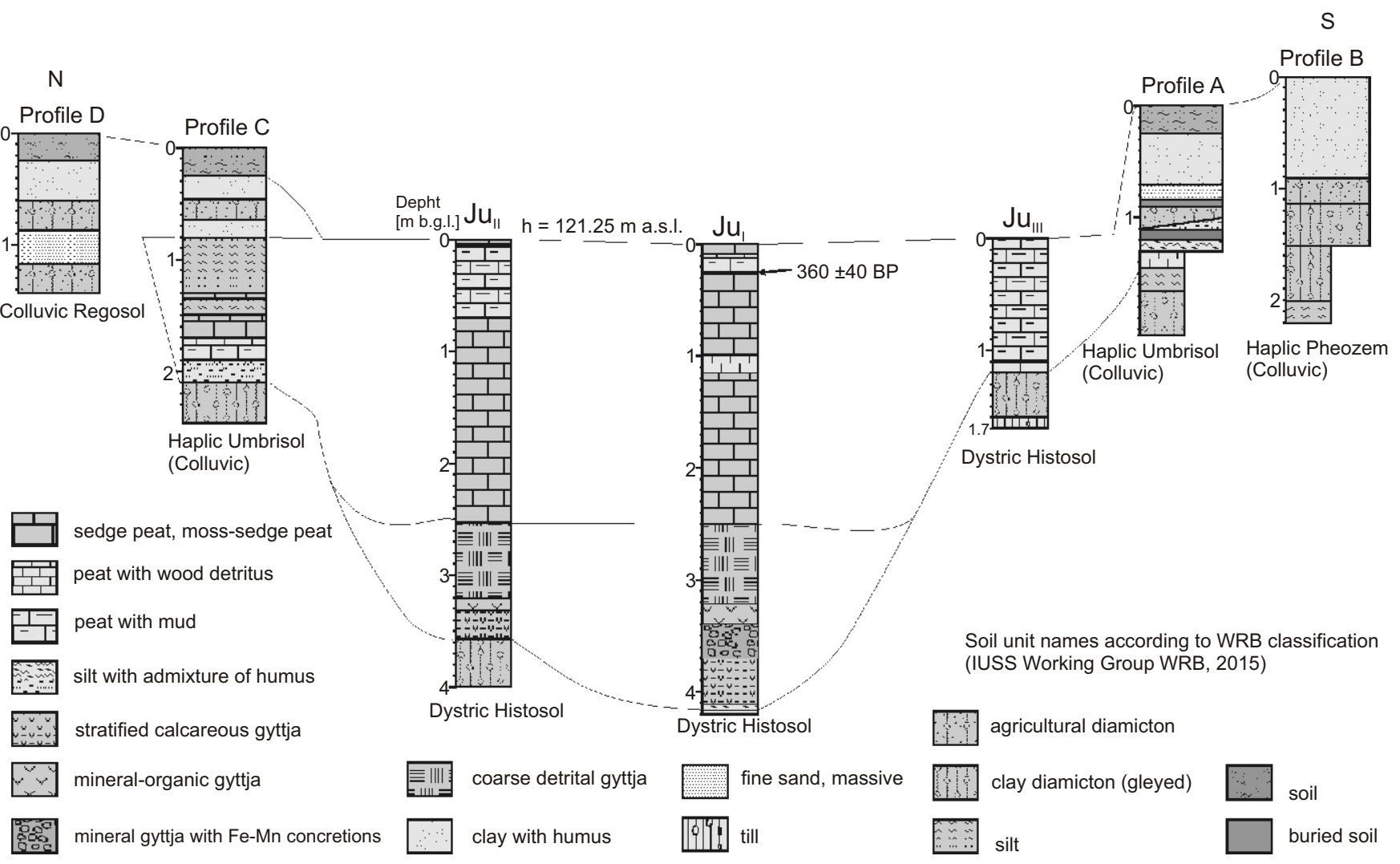

Fig. 2. The geological structure of the slopes and bottom of the kettle hole 
(Noryśkiewicz, 1987, 2013; Ralska-Jasiewiczowa et al., 1998). Moreover, the history of local vegetation was completed with the results of macroremains analysis (in total, 6 local macrofossil assemblage zones - L MAZ; Fig. 5). A synthetic description of the stratigraphy and lithology of the deposits studied correlated with $L P A Z$ and $L M A Z$ is presented in Figure 6 . The following chronozones were distinguished: $3.40-4.20 \mathrm{~m}$ - the Late Glacial (the top sediment sample was characterized by mixed taxa of the Late Glacial and the Holocene; Fig. 4);
3.20-3.40 m - a hiatus from the Preboreal, Boreal and Early Atlantic periods; $2.90-3.20 \mathrm{~m}$ - the Late Atlantic; 0.0-2.80 m - the Subboreal and Subatlantic.

In addition to well-preserved sporomorphs, the Late Glacial deposits $(3.40-4.20 \mathrm{~m})$ in the $\mathrm{Ju}_{\text {, }}$ profile contained reworked material (Ilex, Sequoia, Hystrix). On the other hand, the overlying segment 3.20-3.40 m comprised pollen-free deposits with corroded fern spores and fragments of broken Fe-Mn concretions. The upper part of the remaining sediment was character-
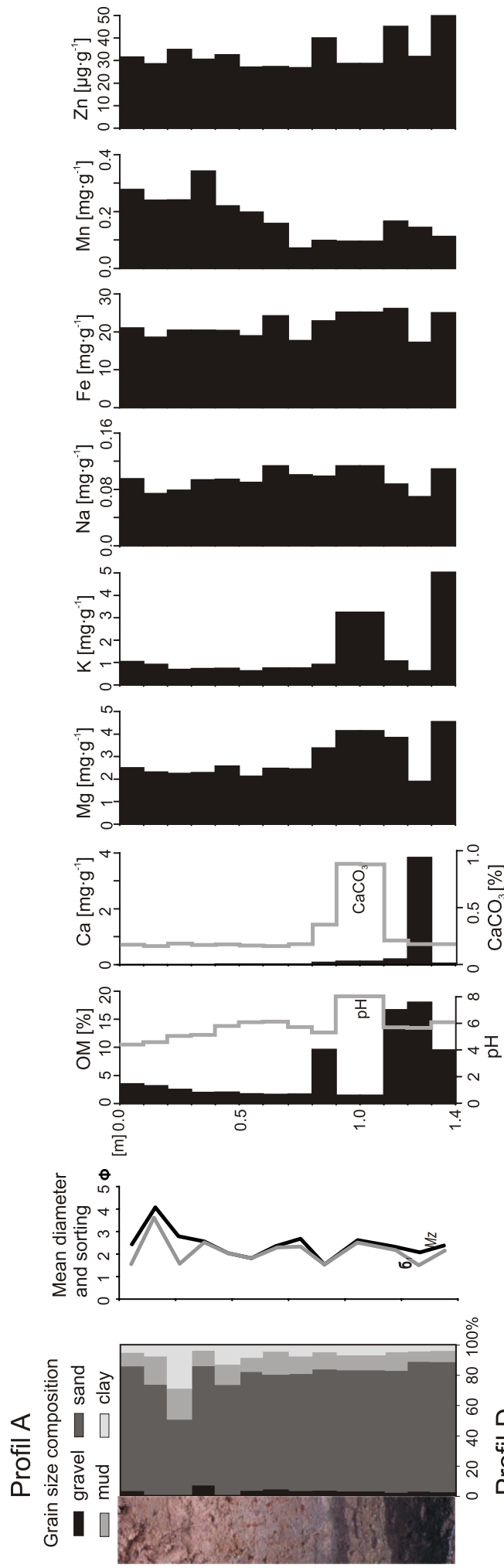
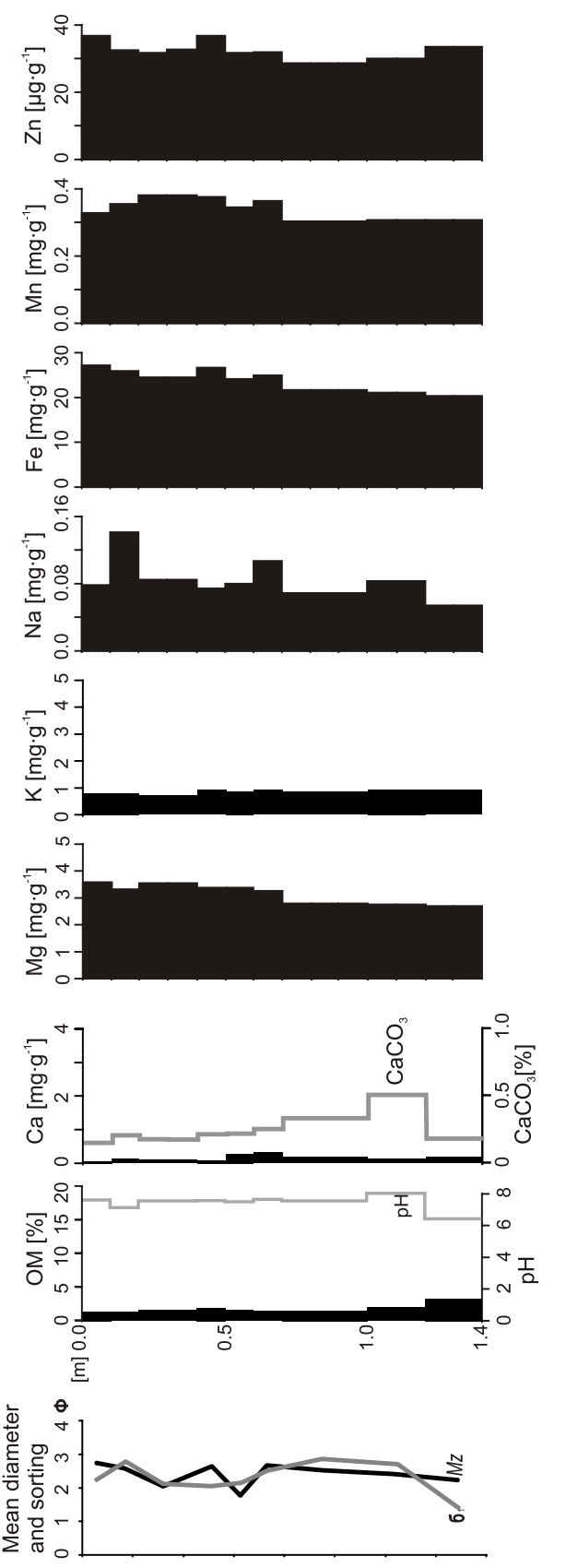

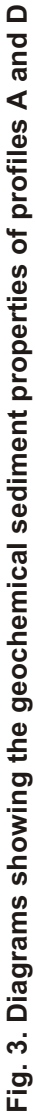

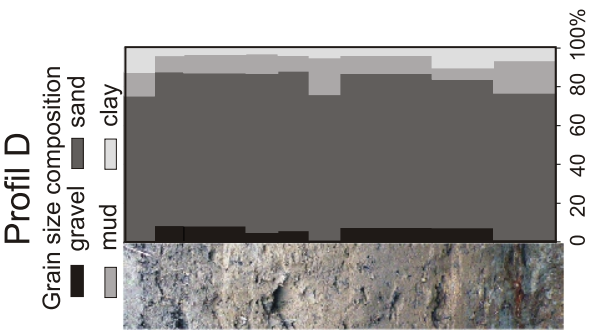




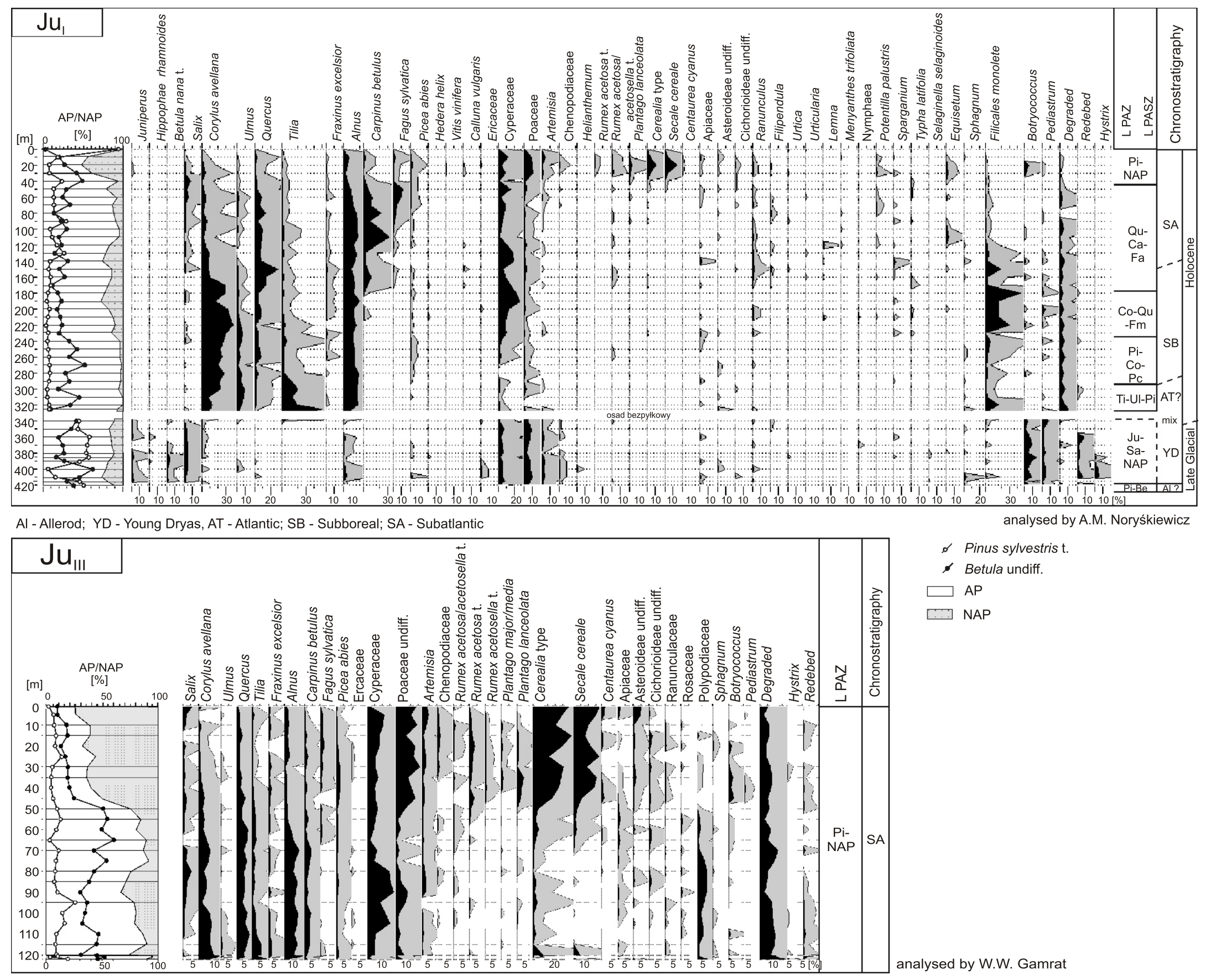




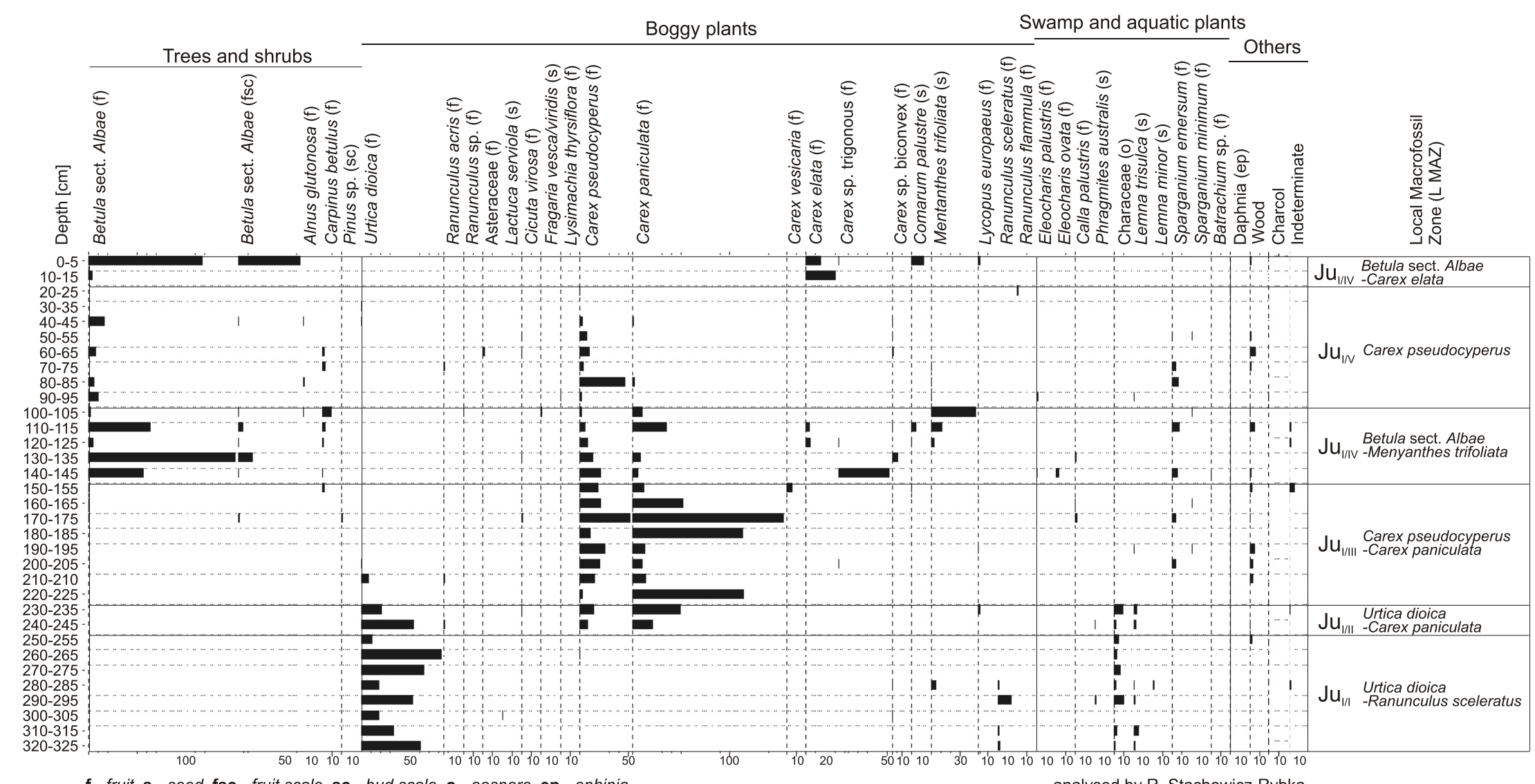

f - fruit, s - seed, fsc - fruit scale, sc - bud scale, o - oospore, ep - ephipia

analysed by R. Stachowicz-Rybka

Fig. 5. Macroremains diagram for the $\mathrm{Ju}_{1}$ core 


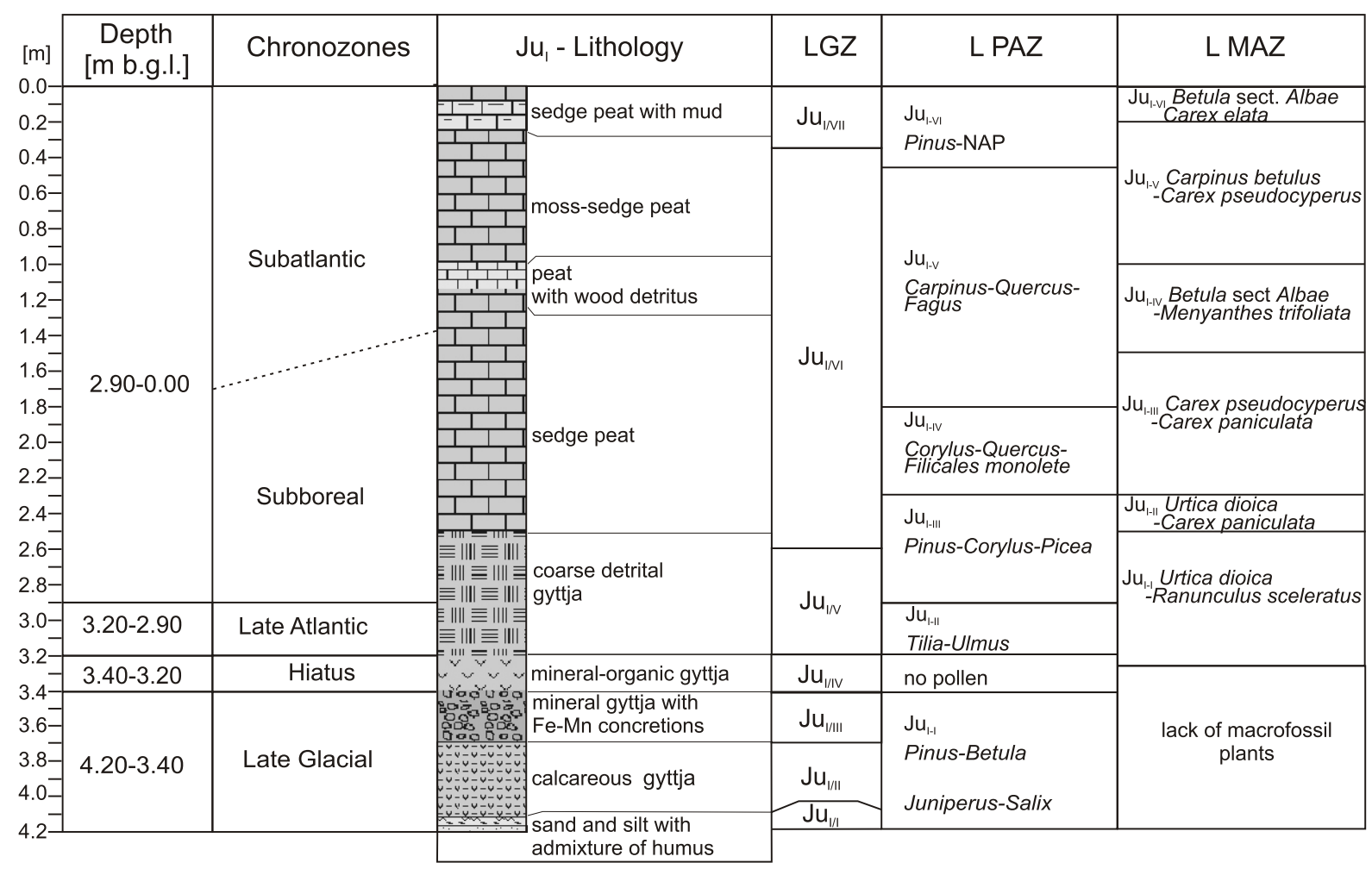

Fig. 6. Chronozones marked in the Ju, sediment core

Lithological description as on Figure 2

ized by a high content of sporomorphs, corroded to a lesser or greater extent (e.g., the degraded curve - Fig. 4). Therefore, the results of pollen analysis for profiles $\mathrm{J} \mathrm{u}_{l}$ and $\mathrm{J} \mathrm{u}_{\| I}$ are difficult to interpret.

\section{GEOCHEMISTRY}

Slope sediments. Sediments of profiles $A$ and $D$ are distinguished by a varying content of organic matter $(A-1.5-18.0 \%$; $\mathrm{D}-1.4-3.3 \%)$ and a low content of $\mathrm{Ca}\left(0.01-3.84 \mathrm{mg} \cdot \mathrm{g}^{-1}\right.$ and $0.06-0.31 \mathrm{mg} \cdot \mathrm{g}^{-1}$, respectively; Fig. 3). The highest content of OM was determined in the buried soil horizons (profile $A$; $0.80-0.90 \mathrm{~m}$ and $1.10-1.20 \mathrm{~m}$ ). The content of potassium (up to $5.3 \mathrm{mg} \cdot \mathrm{g}^{-1}$ ) and magnesium (up to $4.6 \mathrm{mg} \cdot \mathrm{g}^{-1}$ ) was higher in the sediments of profile A compared to profile $D$ (accumulation in the deeper mineral sediment layer). On the other hand, sediments of the latter profile were characterized by a higher content of such metals as $\mathrm{Mg}, \mathrm{Fe}, \mathrm{Mn}$, and $\mathrm{Zn}$ (Fig. 7). The range of $\mathrm{pH}$ values varied greatly (profile $\mathrm{A}-4.2-7.7$; profile $\mathrm{D}$ 6.4-8.1). The lowest $\mathrm{pH}$ values were recorded in colluvial sediments of profile $A$, and the highest in the levels containing $\mathrm{CaCO}_{3}$ (up to $0.8 \%$; Fig. 3).

Bottom sediments. Properties of the bottom sediments of the kettle hole studied were described based on the samples collected from two cores at sites $\mathrm{Ju}_{\mathrm{l}}$ and $\mathrm{Ju}_{\| I}$. The attention was focused mainly on the former due to its location in the central part of the bottom and a complete sequence of bottom sediments.

The seven geochemical zones (from $\mathrm{Ju}_{\mathrm{I} / \mathrm{I}}$ to $\mathrm{Ju}_{\mathrm{I} / \mathrm{NI}}$ ) were identified in the Ju, core by hierarchical cluster analysis (Fig. 7). As shown in Table 1, the zones differ significantly in their chemical properties. The most important features of these zones are described below.
The $\mathrm{Ju}_{\mathrm{I} / \mathrm{l}}$ zone (4.10-4.20 m; sand, organic silt), which represents the bottom layer of the sediment sequence, was characterized by a slightly alkaline reaction $(\mathrm{pH} 7.3-7.9)$ and by considerable enrichment with organic matter (OM 4.6-14.3\%). The content of OM was determined as a loss on ignition and therefore the values obtained may be somewhat overstated (as in $\mathrm{Ju}_{/ / 11}$ ) due to the very high concentration of carbonates. The zone was distinguished by the maximum (in relation to the whole profile) $\mathrm{Fe}(274$ $\left.\mathrm{mg} \cdot \mathrm{g}^{-1}\right)$ and $\mathrm{Mn}$ content $\left(10.2 \mathrm{mg} \cdot \mathrm{g}^{-1}\right)$ as well as a very high content of $\mathrm{SiO}_{2 \text { ter }}$ (up to $64.2 \%$ ), $\mathrm{Ca}$ (up to $212 \mathrm{mg} \cdot \mathrm{g}^{-1}$ ), and $\mathrm{CaCO}_{3}$ (up to $30 \%$ ) (Fig. 7). Low values of geochemical indicators, i.e. $\mathrm{Na}: \mathrm{K}(0.10-0.12)$, Ca:Fe (0.1-3.5) and Fe:Mn (28-68) were determined. A relatively high ratio of $\mathrm{Ca}: \mathrm{Mg}(7-36)$ may be connected with a high content of carbonates.

The $\mathrm{Ju}_{\mathrm{I} / \mathrm{II}}$ zone (3.70-4.10 m; mineral gyttja) had a lower content of OM (minimum for the whole profile $-2.5 \%$ ) and a higher content of $\mathrm{SiO}_{2 \text { ter }}$ compared to $\mathrm{Ju}_{/ / 1}$ (up to $67.3 \%$ ). The maximum values for the whole profile were recorded for $\mathrm{Ca}$ (up to $\left.249 \mathrm{mg} \cdot \mathrm{g}^{-1}\right), \quad \mathrm{CaCO}_{3}(46.5 \%), \quad \mathrm{K} \quad\left(3.3 \mathrm{mg} \cdot \mathrm{g}^{-1}\right), \quad \mathrm{Mg}$ $\left(7.2 \mathrm{mg} \cdot \mathrm{g}^{-1}\right), \mathrm{Na}\left(0.22 \mathrm{mg} \cdot \mathrm{g}^{-1}\right)$, and $\mathrm{pH}(8.2)$. Furthermore, a significant reduction in the content of $\mathrm{Fe}$ and $\mathrm{Mn}$ was determined. The indicators $\mathrm{Ca}: \mathrm{Mg}$ and Fe:Mn significantly increased (up to 43 and 120, respectively), and the Ca:Fe ratio had the maximum value throughout the profile (15.8). Values of the $\mathrm{Na}: \mathrm{K}$ ratio were similar to $\mathrm{Ju}_{/ / /}$.

Sediments in the $\mathrm{Ju}_{\mathrm{I} / \| !}$ zone (3.40-3.70 m; mineral gyttja with Fe-Mn concretions) were moderately rich in organic matter (OM 6.9-17.0\%). Compared to $\mathrm{Ju}_{\mathrm{I} / \mathrm{ll}}$, a decrease in $\mathrm{pH}$ values and in the content of $\mathrm{SiO}_{2 \text { ter, }} \mathrm{Ca}, \mathrm{CaCO}_{3}, \mathrm{~K}, \mathrm{Mg}$, and $\mathrm{Na}$ was determined, along with a very large increase in the content of $\mathrm{Fe}$ (up to $245 \mathrm{mg} \cdot \mathrm{g}^{-1}$ ), Mn (up to $8.6 \mathrm{mg} \cdot \mathrm{g}^{-1}$ ), and $\mathrm{Zn}$ (up to $129 \mathrm{mg} \cdot \mathrm{g}^{-1}$ ). In this zone, a significant decrease in the values of Ca:Fe (min. 


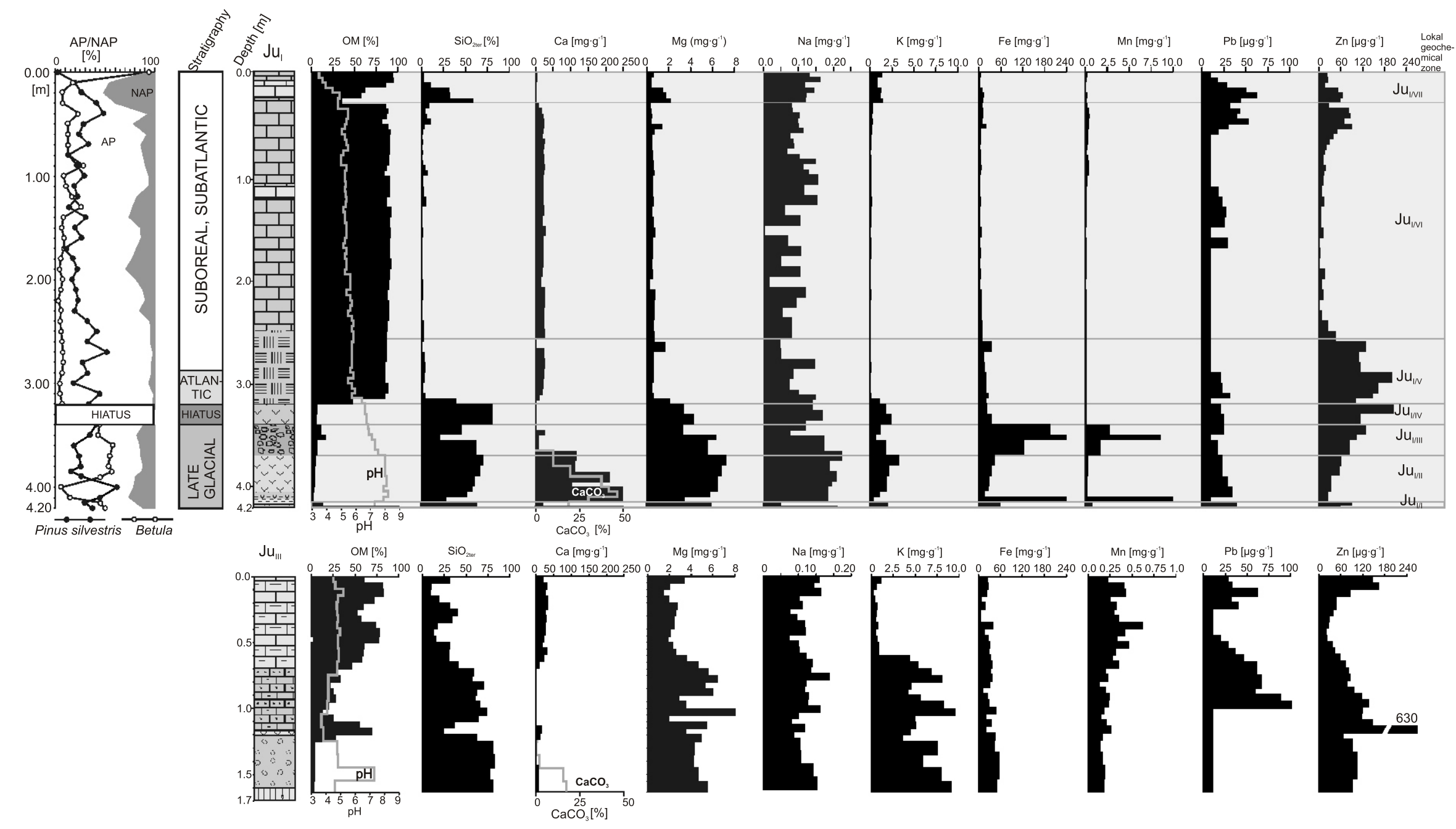

Fig. 7. Geochemical properties of the $J u_{I}$ and $J u_{\mid I}$ core sediments

Lithological description as for Figure 
Table 1

Statistical measures of the analysed sediment parameters (mean \pm standard deviation, range), Ju, core

\begin{tabular}{|c|c|c|c|c|c|c|c|}
\hline \multirow{2}{*}{ Parameter } & \multicolumn{7}{|c|}{ Local geochemical zones } \\
\hline & $I(n=2)$ & II $(n=5)$ & III $(n=5)$ & $\mathrm{IV}(\mathrm{n}=5)$ & $V(n=11)$ & VI $(n=29)$ & VII $(n=7)$ \\
\hline $\begin{array}{l}\mathrm{OM} \\
{[\%]}\end{array}$ & $\begin{array}{c}9.5 \pm 6.8 \\
(4.6-14.3)\end{array}$ & $\begin{array}{c}3.7 \pm 0.9 \\
(2.5-4.9)\end{array}$ & $\begin{array}{c}9.4 \pm 5.1 \\
(6.9-17.0)\end{array}$ & $\begin{array}{c}9.7 \pm 23.7 \\
(5.8-47.6)\end{array}$ & $\begin{array}{c}87.1 \pm 1.4 \\
(85.8-89.1)\end{array}$ & $\begin{array}{c}90.2 \pm 5.7 \\
(61.6-92.9)\end{array}$ & $\begin{array}{c}70.5 \pm 22.6 \\
(35.4-95.0)\end{array}$ \\
\hline $\begin{array}{l}\mathrm{SiO}_{2 \text { ter }} \\
{[\%]}\end{array}$ & $\begin{array}{c}46.1 \pm 25.7 \\
(27.9-64.2)\end{array}$ & $\begin{array}{c}63.0 \pm 6.4 \\
(52.1-67.3)\end{array}$ & $\begin{array}{c}46.8 \pm 20.7 \\
(21.0-62.1)\end{array}$ & $\begin{array}{c}70.1 \pm 23.9 \\
(39.5-80.9)\end{array}$ & $\begin{array}{c}2.7 \pm 1.3 \\
(1.3-4.5)\end{array}$ & $\begin{array}{c}1.4 \pm 2.4 \\
(0.1-11.0)\end{array}$ & $\begin{array}{l}12.5 \pm 20.8 \\
(2.7-59.1)\end{array}$ \\
\hline $\begin{array}{l}\mathrm{CaCO}_{3} \\
{[\%]}\end{array}$ & $\begin{array}{c}24.6 \pm 7.7 \\
(19.2-30.0)\end{array}$ & $\begin{array}{c}32.5 \pm 13.4 \\
(16.7-46.5) \\
\end{array}$ & $\begin{array}{c}4.0 \pm 2.4 \\
(1.4-6.2) \\
\end{array}$ & $\begin{array}{c}0.48 \pm 0.56 \\
(0.11-1.12)\end{array}$ & - & - & - \\
\hline $\begin{array}{l}\mathrm{Ca} \\
{\left[\mathrm{mg} \cdot \mathrm{g}^{-1}\right]}\end{array}$ & $\begin{array}{c}117 \pm 133 \\
(23.0-212) \\
\end{array}$ & $\begin{array}{l}145 \pm 67.0 \\
(104-249) \\
\end{array}$ & $\begin{array}{c}4.4 \pm 13.2 \\
(0.5-26.7) \\
\end{array}$ & $\begin{array}{c}0.6 \pm 6.5 \\
(0.2-11.5)\end{array}$ & $\begin{array}{c}15.2 \pm 9.6 \\
(1.6-27.4) \\
\end{array}$ & $\begin{array}{c}23.8 \pm 2.7 \\
(16.3-28.2) \\
\end{array}$ & $\begin{array}{c}1.9 \pm 3.1 \\
(0.1-8.3) \\
\end{array}$ \\
\hline $\begin{array}{l}\mathrm{Mg} \\
{[\mathrm{mg} \cdot \mathrm{g}-1]}\end{array}$ & $\begin{array}{c}4.7 \pm 1.7 \\
(3.5-5.9)\end{array}$ & $\begin{array}{c}6.6 \pm 0.5 \\
(5.8-7.2) \\
\end{array}$ & $\begin{array}{c}4.8 \pm 1.6 \\
(3.3-6.3)\end{array}$ & $\begin{array}{c}3.4 \pm 1.1 \\
(2.2-4.3)\end{array}$ & $\begin{array}{c}0.7 \pm 0.5 \\
(0.5-1.7)\end{array}$ & $\begin{array}{c}0.6 \pm 0.2 \\
(0.3-1.4)\end{array}$ & $\begin{array}{c}0.8 \pm 0.8 \\
(0.4-2.2) \\
\end{array}$ \\
\hline $\mathrm{K}$ & $\begin{array}{c}1.3 \pm 1.2 \\
(0.4-2.1)\end{array}$ & $\begin{array}{c}2.1 \pm 0.8 \\
(1.1-3.3)\end{array}$ & $\begin{array}{c}1.3 \pm 0.6 \\
(0.7-1.8)\end{array}$ & $\begin{array}{c}1.8 \pm 0.7 \\
(1.1-2.4)\end{array}$ & $\begin{array}{c}0.1 \pm<0.1 \\
(0.07-0.12)\end{array}$ & $\begin{array}{c}0.1 \pm 0.1 \\
(0.05-0.31)\end{array}$ & $\begin{array}{c}1.0 \pm 0.4 \\
(0.3-1.5)\end{array}$ \\
\hline $\begin{array}{l}\mathrm{Na} \\
{\left[\mathrm{mg} \cdot \mathrm{g}^{-1}\right]}\end{array}$ & $\begin{array}{c}0.1 \pm 0.1 \\
(0.05-0.21)\end{array}$ & $\begin{array}{c}0.2 \pm<0.1 \\
(0.19-0.22)\end{array}$ & $\begin{array}{c}0.1 \pm 0.1 \\
(0.08-0.17)\end{array}$ & $\begin{array}{c}0.2 \pm<0.1 \\
(0.14-0.17)\end{array}$ & $\begin{array}{c}0.1 \pm<0.1 \\
(0.05-0.15)\end{array}$ & $\begin{array}{c}0.1 \pm<0.1 \\
(0.01-0.16)\end{array}$ & $\begin{array}{c}0.1 \pm 0.0 \\
(0.08-0.16)\end{array}$ \\
\hline $\begin{array}{l}\mathrm{Fe} \\
{\left[\mathrm{mg} \cdot \mathrm{g}^{-1}\right]}\end{array}$ & $\begin{array}{c}167 \pm 151 \\
(60.3-274)\end{array}$ & $\begin{array}{c}30.6 \pm 10.2 \\
(15.8-43.5) \\
\end{array}$ & $\begin{array}{c}166 \pm 61.5 \\
(122-245)\end{array}$ & $\begin{array}{c}26.2 \pm 8.6 \\
(20.0-35.8) \\
\end{array}$ & $\begin{array}{c}20.7 \pm 7.5 \\
(14.4-35.2)\end{array}$ & $\begin{array}{c}5.7 \pm 3.4 \\
(3.5-20.3)\end{array}$ & $\begin{array}{c}6.1 \pm 4.3 \\
(2.7-13.1) \\
\end{array}$ \\
\hline $\begin{array}{l}\mathrm{Mn} \\
{\left[\mathrm{mg} \cdot \mathrm{g}^{-1}\right]}\end{array}$ & $\begin{array}{c}5.5 \pm 6.5 \\
(0.9-10.2) \\
\end{array}$ & $\begin{array}{c}0.3 \pm 0.1 \\
(0.2-0.4) \\
\end{array}$ & $\begin{array}{c}2.7 \pm 3.7 \\
(1.7-8.6) \\
\end{array}$ & $\begin{array}{c}0.1 \pm<0.1 \\
(0.11-0.17)\end{array}$ & $\begin{array}{c}0.2 \pm<0.1 \\
(0.16-0.20)\end{array}$ & $\begin{array}{c}0.2 \pm 0.1 \\
(0.08-0.51)\end{array}$ & $\begin{array}{c}0.1 \pm 0.1 \\
(0.06-0.27)\end{array}$ \\
\hline $\begin{array}{l}\mathrm{Pb} \\
{\left[\mu \mathrm{g} \cdot \mathrm{mg}^{-1}\right]}\end{array}$ & $\begin{array}{l}25.0 \pm 21.3 \\
(10.0-40.1)\end{array}$ & $\begin{array}{c}26.9 \pm 6.0 \\
(22.7-26.3)\end{array}$ & $\begin{array}{c}17.9 \pm 7.3 \\
(10.0-24.5)\end{array}$ & $\begin{array}{c}19.5 \pm 7.8 \\
(10.0-25.1)\end{array}$ & $\begin{array}{c}14.9 \pm 9.1 \\
(10.0-23.2)\end{array}$ & $\begin{array}{c}14.1 \pm 11.9 \\
(10.0-52.9)\end{array}$ & $\begin{array}{c}30.2 \pm 18.4 \\
(10.0-62.5)\end{array}$ \\
\hline $\mathrm{Zn}$ & $\begin{array}{c}76.2 \pm 21.1 \\
(61.3-91.1)\end{array}$ & $\begin{array}{l}43.6 \pm 15.2 \\
(26.3-60.8)\end{array}$ & $\begin{array}{c}101 \pm 21.9 \\
(85.1-129)\end{array}$ & $\begin{array}{c}141 \pm 56.2 \\
(102-205)\end{array}$ & $\begin{array}{c}140 \pm 34.4 \\
(109-200)\end{array}$ & $\begin{array}{l}12.5 \pm 26.4 \\
(2.0-90.3)\end{array}$ & $\begin{array}{c}34.3 \pm 19.8 \\
(16.3-66.3)\end{array}$ \\
\hline $\mathrm{pH}$ & $\begin{array}{c}7.6 \pm 0.4 \\
(7.3-7.9) \\
\end{array}$ & $\begin{array}{c}8.0 \pm 0.1 \\
(7.9-8.2) \\
\end{array}$ & $\begin{array}{c}7.1 \pm 0.6 \\
(6.8-6.3) \\
\end{array}$ & $\begin{array}{c}6.6 \pm 0.2 \\
(6.4-6.7) \\
\end{array}$ & $\begin{array}{l}5.7 \pm<0.1 \\
(5.7-5.8) \\
\end{array}$ & $\begin{array}{c}5.4 \pm 0.2 \\
(5.1-5.8) \\
\end{array}$ & $\begin{array}{c}4.5 \pm 0.5 \\
(3.8-5.0) \\
\end{array}$ \\
\hline Na:K & $\begin{array}{c}0.1 \pm<0.1 \\
(0.10-0.12) \\
\end{array}$ & $\begin{array}{c}0.1 \pm<0.1 \\
(0.07-0.17) \\
\end{array}$ & $\begin{array}{c}0.1 \pm<0.1 \\
(0.09-0.12)\end{array}$ & $\begin{array}{c}0.1 \pm<0.1 \\
(0.07-0.13) \\
\end{array}$ & $\begin{array}{c}0.8 \pm 0.2 \\
(0.6-1.2) \\
\end{array}$ & $\begin{array}{c}0.7 \pm 0.3 \\
(0.1-1.3) \\
\end{array}$ & $\begin{array}{c}0.1 \pm 0.1 \\
(0.1-0.3) \\
\end{array}$ \\
\hline Fe:Mn & $\begin{array}{c}48 \pm 29 \\
(28-68)\end{array}$ & $\begin{array}{c}105 \pm 21 \\
(69-120)\end{array}$ & $\begin{array}{c}56 \pm 24 \\
(28-71)\end{array}$ & $\begin{array}{c}183 \pm 39 \\
(138-210)\end{array}$ & $\begin{array}{c}123 \pm 38 \\
(85-179)\end{array}$ & $\begin{array}{c}33 \pm 17 \\
(14-68)\end{array}$ & $\begin{array}{c}51 \pm 27 \\
(14-86) \\
\end{array}$ \\
\hline Ca:Mg & $\begin{array}{l}21 \pm 21 \\
(7-36)\end{array}$ & $\begin{array}{c}25 \pm 12 \\
(16-43)\end{array}$ & $\begin{array}{c}2 \pm 2 \\
(<1-4)\end{array}$ & $\begin{array}{c}2 \pm 3 \\
(<1-5)\end{array}$ & $\begin{array}{l}34 \pm 17 \\
(1-46)\end{array}$ & $\begin{array}{c}40 \pm 7 \\
(19-53) \\
\end{array}$ & $\begin{array}{c}8 \pm 8 \\
(<1-23)\end{array}$ \\
\hline $\mathrm{Ca}: \mathrm{Fe}$ & $\begin{array}{c}1.8 \pm 2.4 \\
(0.1-3.5) \\
\end{array}$ & $\begin{array}{c}6.6 \pm 5.6 \\
(2.7-15.8)\end{array}$ & $\begin{array}{c}0.1 \pm 0.1 \\
(<0.1-0.1)\end{array}$ & $\begin{array}{c}0.2 \pm 0.3 \\
(<0.1-0.6)\end{array}$ & $\begin{array}{c}1.1 \pm 0.6 \\
(0.1-1.7)\end{array}$ & $\begin{array}{c}4.3 \pm 1.3 \\
(1.3-6.5)\end{array}$ & $\begin{array}{c}0.9 \pm 0.9 \\
(<0.1-2.1)\end{array}$ \\
\hline
\end{tabular}

$<0.1)$, Fe:Mn (28-71) and Ca:Mg (min. <1) was recorded. Values of the Na:K ratio were similarly low as in older horizons.

The Ju/lv zone (3.20-3.40 m; mineral-organic gyttja) was distinguished by the presence of slightly acid deposits $(\mathrm{pH}$ 6.4-6.7) with a highly varied content of organic matter and terrigenous silica, i.e. 6 and $81 \%$ (the profile's maximum) in the floor and 48 and $40 \%$ in the top, respectively. Compared to $\mathrm{Ju}_{\mathrm{I} / \mathrm{III}}$, a significant decrease in the content of $\mathrm{Ca}$ (up to $0.2 \mathrm{mg} \cdot \mathrm{g}^{-1}$ ), $\mathrm{Mn}$ (up to $0.1 \mathrm{mg} \cdot \mathrm{g}^{-1}$ ), and $\mathrm{Mg}$ (up to $3.3 \mathrm{mg} \cdot \mathrm{g}^{-1}$ ) was determined in this zone, and there was a major increase in the content of $\mathrm{Zn}$ (maximum for the profile $-205 \mu \mathrm{g} \cdot \mathrm{g}^{-1}$ ). Furthermore, the maximum values of the Fe:Mn ratio (210) were determined and there was a considerable decrease in the values of $\mathrm{Fe}: \mathrm{Ca}, \mathrm{Na}: \mathrm{K}$, and $\mathrm{Ca}: \mathrm{Mg}$ ratios, which were equally low as in the $\mathrm{Ju}_{\mathrm{I} / \mathrm{II}}$ zone.

The Ju $\mathrm{IIN}_{\mathrm{I}}$ zone (2.60-3.20 m; coarse detrital gyttja) was distinguished by a sudden increase in the organic matter content (OM 86-89\%), with a simultaneous major decrease in the content of terrigenous silica $\left(\mathrm{SiO}_{2 \text { ter }} 1.3-4.5 \%\right), \mathrm{K}$ $\left(0.07-0.12 \mathrm{mg} \cdot \mathrm{g}^{-1}\right)$, and $\mathrm{Mg}\left(0.3-1.4 \mathrm{mg} \cdot \mathrm{g}^{-1}\right)$. The content of $\mathrm{Zn}$ remained at a level above $100 \mu \mathrm{g} \cdot \mathrm{g}^{-1}$ (Fig. 7). The $\mathrm{pH}$ values ranged from 5.7 to 5.8 , which indicated acidification of the environment. Contrary to the Fe:Mn ratio (85-179), values of $\mathrm{Na}: \mathrm{K}$ (0.6-1.2), Ca:Mg (1-46) and Ca:Fe (0.1-1.7) ratios increased.
The Ju $\mathrm{u}_{I N \mid}$ zone $(0.35-2.60 \mathrm{~m}$; coarse detrital gyttja at the floor, sedge peat and moss-sedge peat at the top) was distinguished by a very high content of organic matter and a small content of terrigenous silica (the minimum value of $0.1 \%$ ). These parameters varied, however, to a larger extent compared to $\mathrm{Ju}_{\mathrm{IN}}\left(\mathrm{OM} 62-93 \%, \mathrm{SiO}_{2 \text { ter }} 0.1-11 \%\right)$. The sediments were acidic ( $\mathrm{pH}$ 5.1-5.8) with particularly poor concentrations of potassium and magnesium, which occurred with the minimum values in this zone $\left(\mathrm{K} 0.05 \mathrm{mg} \cdot \mathrm{g}^{-1}, \mathrm{Mg} 0.3 \mathrm{mg} \cdot \mathrm{g}^{-1}\right)$. In the uppermost layer of the zone, the concentrations of $\mathrm{Pb}$ (up to $52.9 \mu \mathrm{g} \cdot \mathrm{g}^{-1}$ ) and $\mathrm{Zn}$ (up to $90.3 \mu \mathrm{g} \cdot \mathrm{g}^{-1}$ ) significantly increased. Furthermore, a small increase in the values of Ca:Fe (1.3-6.5), Ca:Mg (19-53), and $\mathrm{Na:K}$ (up to 1.3 - the maximum value in the profile) and a considerable decline in values of the Fe:Mn ratio (14-68) was observed.

The Ju $\mathrm{u}_{I N I}$ zone $(0.0-0.35 \mathrm{~m}$; peat) was characterized by a wide range of organic matter content (35-95\%). With respect to $\mathrm{Ju}_{1 N \mid}$, a significant increase in the content of $\mathrm{SiO}_{2 \text { ter }}$ (up to $59.1 \%), \mathrm{Mg}\left(0.4-2.2 \mathrm{mg} \cdot \mathrm{g}^{-1}\right)$, and $\mathrm{K}\left(0.3-1.5 \mathrm{mg} \cdot \mathrm{g}^{-1}\right)$ was determined. $\mathrm{Fe}$ and $\mathrm{Mn}$ reached their profile minima (2.7 and $0.06 \mathrm{mg} \cdot \mathrm{g}^{-1}$, respectively). The content of lead and zinc largely varied $\left(\mathrm{Pb} 10.0-62.5 \mu \mathrm{g} \cdot \mathrm{g}^{-1} ; \mathrm{Zn} 16.3-66.3 \mu \mathrm{g} \cdot \mathrm{g}^{-1}\right.$ ) and significantly dropped in the last $10 \mathrm{~cm}$ of the roof. A large decrease in $\mathrm{pH}$ values towards the roof of sediments was observed, which 
were very acidic at the surface $(\mathrm{pH} 3.8)$. Values of geochemical indices, except for Fe:Mn (14-86), were much lower compared to $\mathrm{Ju}_{|\mathrm{N}| \text {. }}$

Figure 8 presents scatter plots between the content of terrigenous silica $\left(\mathrm{SiO}_{2 \text { ter }}\right)$ and the content of organic matter $(\mathrm{OM})$ and selected metals in the whole $\mathrm{Ju}_{1}$ profile. A highly significant negative correlation between $\mathrm{SiO}_{2 \text { ter }}$ and $\mathrm{OM}$ was recorded $(r$ value $-0.944, p=0.000$ ), whereas a significant positive correlation was found only for $\mathrm{Na}, \mathrm{K}, \mathrm{Mg}, \mathrm{Fe}, \mathrm{Pb}, \mathrm{Zn}$ - elements closely connected with lithological conditions of the drainage basin. $\mathrm{K}$ and $\mathrm{Mg}$ demonstrated the strongest correlation with $\mathrm{SiO}_{2 \text { ter }}(\mathrm{r}$ values 0.922 and 0.859 , respectively; $p=0.000$ ). These metals are generally more strongly sorbed by sediments and therefore subject to passive migration together with mineral and organic colloids (Borówka, 1992; Franz et al., 2006).

The bottom part of profile $\mathrm{Ju}_{\text {|II }}$ was built of mineral deposits (loam), which are rich in $\mathrm{CaCO}_{3}$ (ca. 16\%, pH 7.6-8.0) and all the metals analysed (Fig. 7). Paludal sediments of $\mathrm{Ju}_{\text {III }}(1.20-0.0 \mathrm{~m})$ were distinguished by a significant heterogeneity of all the parameters analysed. A considerable enrichment in organic matter (up to $83 \%$ ), Ca (up to $32 \mathrm{mg} \cdot \mathrm{g}^{-1}$ ), $\mathrm{Mn}$ (up to $3.4 \mathrm{mg} \cdot \mathrm{g}^{-1}$ ), $\mathrm{Zn}$ (up to $163 \mu \mathrm{g} \cdot \mathrm{g}^{-1}$ ), and $\mathrm{Pb}$ (up to $61 \mu \mathrm{g} \cdot \mathrm{g}^{-1}$ ) was observed from the depth of $0.65 \mathrm{~m}$ towards the upper part of profile, with the content of terrigenous silica $<40 \%$. Compared to surface layers within the range of $0.65-1.2 \mathrm{~m}$, the content of OM (12-69\%), Ca $\left(0.1-15.8 \mathrm{mg} \cdot \mathrm{g}^{-1}\right), \mathrm{Mn}\left(0.1-0.3 \mathrm{mg} \cdot \mathrm{g}^{-1}\right)$ decreased, while the content of $\mathrm{SiO}_{2 \text { ter }}$ increased (up to $\left.73 \%\right), \mathrm{Mg}\left(1.9-8.3 \mathrm{mg} \cdot \mathrm{g}^{-1}\right), \mathrm{K}$ $\left(4.1-9.5 \mathrm{mg} \cdot \mathrm{g}^{-1}\right)$, and Fe (10.1-47.2 $\left.\mathrm{mg} \cdot \mathrm{g}^{-1}\right)$ (Fig. 7).

\section{DISCUSSION}

The origin of the kettle hole studied is connected with the melting of a dead-ice block and the disappearance of long-term permafrost. According to van Loon et al. (2012), the permafrost mostly developed in the ice-free zone that appeared after the recession of the ice sheet. Consistent with the views of Błaszkiewicz $(2008,2011)$, it was likely that the melting of a buried dead-ice block proceeded relatively quickly in the absence of water runoff from the kettle hole studied and the presence of thermokarst processes. Sediment accumulation of the first local geochemical zone $\mathrm{Ju}_{/ / 1}$ probably still occurred in the periglacial conditions of the initial cold lake, which may be shown by e.g., a low concentration of $\mathrm{Ca}$ (Fig. 7). Then the permafrost underwent a gradual degradation, which resulted in a significant intensification of chemical and mechanical denudation processes in the drainage basin (the maximum content of $\mathrm{Ca}, \mathrm{CaCO}_{3}, \mathrm{~K}, \mathrm{Mg}$, and $\mathrm{Na}$ ) in $\mathrm{Ju}_{/ / I}($ Table 1, Figs. 7 and 8). A layer of mineral gyttja was located at a depth of 3.70-3.40 m, which testifies to the further evolution of the small lake $\left(\mathrm{Ju}_{/ / \mathrm{III}}\right)$. The layer was characterized by a significant enrichment in terrigenous silica, the lack of carbonates, and the presence of ferruginous-manganese concretions. The presence of the latter can probably be associated with post-sedimentation processes, i.e. diagenesis of deposits in the conditions of partial dehydration and/or water-level fluctuations. This suggestion was also supported by the presence of a hiatus above the analysed layer, and the material containing mixed Late
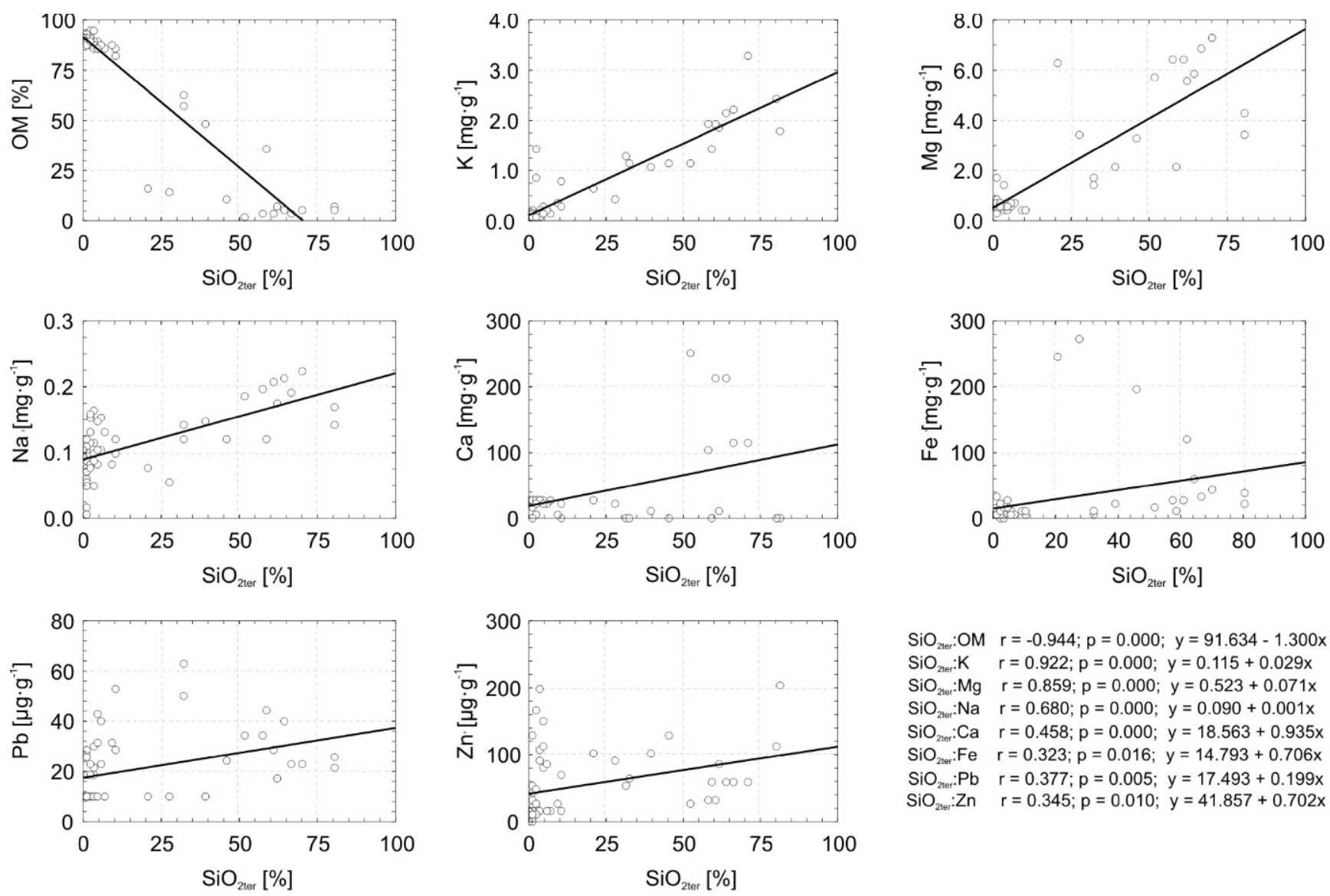

$\mathrm{SiO}_{2}: \mathrm{OM} \quad r=-0.944 ; p=0.000 ; y=91.634-1.300 x$ $\mathrm{SiO}_{2}: \mathrm{K} \quad r=0.922 ; p=0.000 ; y=0.115+0.029 x$ $\mathrm{SiO}_{21 \mathrm{r}}: \mathrm{Mg} \quad \mathrm{r}=0.859 ; \mathrm{p}=0.000 ; \mathrm{y}=0.523+0.071 \mathrm{x}$ $\mathrm{SiO}_{2}: \mathrm{Na} \quad r=0.680 ; p=0.000 ; y=0.090+0.001 x$ $\mathrm{SiO}: \mathrm{Ca} \quad r=0.458 ; p=0.000 ; y=18.563+0.935 x$ $\mathrm{SiO}_{\text {2ter: }}: \mathrm{Fe} \quad r=0.323 ; p=0.016 ; y=14.793+0.706 x$ $\mathrm{SiO}_{2 \mathrm{er}}: \mathrm{Pb} \quad r=0.377 ; p=0.005 ; y=17.493+0.199 x$ $\mathrm{SiO}_{2}: \mathrm{Zn} \quad r=0.345 ; \mathrm{p}=0.010 ; y=41.857+0.702 x$

Fig. 8. Scatter plots of the terrigenous silica $\left(\mathrm{SiO}_{2 \operatorname{ter}}\right)$ content versus the content of organic matter (OM) and selected metals ( $\mathrm{Ju}_{1}$ core) 
Glacial and Holocene taxa (depth $3.40 \mathrm{~m}$; Fig. 4). Mineral-organic gyttja at a depth of 3.20-3.40 m did not contain pollen. A stratigraphical gap occurred during the Preboreal, Boreal, and Early Atlantic periods. Perhaps the reservoir was not completely sealed and in the Early Holocene was drained along with lowering the groundwater level? It is possible in this time that the basin was dry. The likely reason for the presence of sediments with no pollen and macroremains was the desiccation of the depression's bottom, which could contribute to the wind deflation of deposits, and consequently the destruction of pollen grains. Therefore, the interpretation of geochemical indicators for $\mathrm{Ju}_{\mathrm{I} / \mathrm{V}}$, which is characterized by e.g., profile maxima for $\mathrm{Zn}$ and the Fe:Mn ratio (Table 1 and Fig. 7), was in this case very limited. A similar case was described by Mendyk et al. (2015) based on research conducted in the drainage basin of Lake Sumowskie (Brodnica Lake District, north-central Poland). If it is assumed that the accumulation of sediments with a hiatus began in the Preboreal, the water-level lowering in the kettle hole analysed can also be related to similar trends reported from other regions of Poland (e.g., Niewiarowski, 1989, 1995; Starkel et al., 1998; Twardy et al., 2010; Hirsch et al., 2015).

As shown by the palynological analysis, the bottom layer of sediments from the profile $\mathrm{Ju}_{1}$, covering the geochemical levels I, II, and III, should be related to the relatively cold Late Glacial period (Fig. 4). At that time, trees were represented only by pine (Pinus) and birch (Betula), and they were accompanied by heliophilous shrubs and low shrubs (Juniperus, Salix, Betula nana t. and occasionally Hippophae rhamnoides). In addition, plant indicators of cold glacial periods occurred (Dryas octopetala, Selaginella selaginoides and Helianthemum). The redeposited taxa (of Quaternary origin and Neogene, and fragments of dinoflagellates - Hystrix) were also present in relatively large numbers. They probably came from the eluviation of older deposits derived from the drainage basin of the kettle hole, which was possible because of a rather loose vegetation cover. Macroremains have not been preserved in the sediments of these zones.

The presence of coarse detrital gyttja deposits $\mathrm{Ju}_{\mathrm{IN}}$ (the Late Atlantic and Early Subboreal) indicated a change in the sedimentation process and the prevailing telmatic conditions in the depression. However, due to the presence of the above-mentioned hiatus, it was not possible to determine the beginning of the coarse detrital gyttja accumulation. A low content of terrigenous silica and high values of $\mathrm{Na}: \mathrm{K}, \mathrm{Ca}: \mathrm{Mg}$, and $\mathrm{Ca}: \mathrm{Fe}$ indices may indicate the dominance of chemical denudation processes in the drainage basin over mechanical denudation (Table 1 and Fig. 7). In such conditions, a wide range of Fe:Mn values may reflect the variable redox potential associated with water-level fluctuations (Borówka, 1992; Cohen, 2003). Similarly to $\mathrm{Ju}_{\mathrm{I} / \mathrm{V}}$, the geochemical zones analysed were distinguished by a high content of Zn (up to $200 \mu \mathrm{g} \cdot \mathrm{g}^{-1}$ ), caused by bottom-up post-sedimentation migration in the acidic environment (including groundwaters). Taking into account the results obtained by Karasiewicz et al. (2014b), despite the lack of a clear record in the diagrams of pollen and macroremains, one cannot exclude the effect of $\mathrm{Zn}$ bioaccumulation.

Analysis of plant remains from a depth of $3.00-3.25 \mathrm{~m} \mathrm{(L}$ $\mathrm{MAZ} \mathrm{Ju} \mathrm{I}_{-1}$; Fig. 5) showed that in the process of shallowing, the surface of the water body was covered with a Lemnatea pleuston community, the main component of which was Lemna trisulca. The presence of rare fruits of Lemna trisulca in the top part of the zone suggests increased trophy and calcium carbonate content in the water reservoir (Szoszkiewicz et al., 2010), but in the deposit there was no $\mathrm{CaCO}_{3}$. This could have occurred when the environmental conditions did not favour the precipitation of calcium carbonate. Urtica dioica occurred along the shores in nitrogen-rich waterlogged places. Periodically emerged, highly eutrophic places were overgrown with Ranunculus sceleratus. A lack of tree remains and the presence of Lactuca serriola - a species occurring in dry and sunlit habitats - may indicate the supply of material from places located farther from the shores of the water body. This corresponded to L PAZ Ju $\mathrm{u}_{-3}$ (Ti-UI 2.70-3.20 m; Fig. 4) where pollen grains have traces of intensive corrosion and pollen spectra are distinguished by a large number of Tilia pollen, which is rather unusual in the study area (Kupryjanowicz et al., 2004; Bałaga and Chodorowski, 2006). Linden produces rather large amounts of pollen, but the grains are relatively large and heavy (Dyakowska, 1959), hence the genus is rather underrepresented in "pollen rain" (Środoń, 1991). Nevertheless, sporoderm of linden pollen is relatively resistant to the destruction, which means that they can be identified even when they are heavily damaged; this could explain their over-representation in the sediment (Bałaga and Chodorowski, 2006). In the same segment of sediment, there were sporomorphs and NPP (non pollen palynomorphs) coming from the pre-Quaternary sediments (including, e.g., sequoias, Neogene spores, and dinoflagellates Hystrix - marine organisms - Ju $u_{\text {III }}$; Fig. 4), which showed the transport of older material from the drainage basin surrounding the peat bog.

The Late Subboreal and the Early Subatlantic were represented by genetically diverse sediments of $\mathrm{Ju}_{I N \mid}$, i.e. coarse detrital gyttja at the bottom part and sedge peat in the top (Fig. 6). Based on the analysis of geochemical indicators (Na:K, Ca:Mg, Fe:Mn), it can be concluded that sedimentation of these deposits occurred in varying denudation conditions of the drainage basin (Table 1; Figs. 7 and 8 ) and with considerable water-level fluctuations. The water-level rise in the Early Subatlantic is generally recorded in lacustrine and peat-bog sediments of the young glacial area in Poland (Kowalewski, 2014). Similar changes were documented in the pollen and macroremain diagram created for profile Ju (Figs. 4 and 5). They were particularly well-visible for L PAZ J $\mathrm{J}_{-6}$ (Qu-Ca-Fa), L MAZ J J-2 (Urtica dioica-Carex paniculata), and $\mathrm{J}_{-3}$ (Carex pseudocyperus-Carex paniculata). A high content of Cyperaceae at a depth of $1.40 \mathrm{~m}$ and Filicales monolete at a depth of $1.50 \mathrm{~m}$ was determined in the pollen spectra obtained. The increase in sedge pollen and the re-occurrence of Sparganium and Lemna may be correlated with a water-level rise, and the previous fern content of several dozen percentage with peat desiccation. A very high contribution of Carex paniculata and C. pseudocyperus fruits was determined in $L$ MAZ $J_{1-2}$ and $J_{1-3}$ (Fig. 5). They suggest a developed telmatic zone. This situation could be accounted for by favourable habitat conditions. In the conditions of a more humid habitat (depth of $1.90 \mathrm{~m}$ ), large amounts of Carex nutlets (depth 2.20 and $1.70-1.80 \mathrm{~m}$ ) and Cyperaceae pollen were produced (Fig. 4). It can be assumed that an increase in the quantity of sedge nutlets in the macroremain material was affected by diagenetic processes (draining of sediment, partial decomposition of organic matter) which led to peat compaction. A similar phenomenon, triggered by a water-level fall and documented by a sudden increase in the contribution of Filicales monolete, was recorded in sediments at many sites (e.g., Noryśkiewicz, 2006; Wysota and Noryśkiewicz, 2011; Gamrat et al., 2014).

Zone $\mathrm{Ju}_{\mathrm{I} N \mid}$ consisted of deposits accumulated in the Late Subatlantic, the properties of which largely reflected a strong human impact. The high intensity of the catchment denudation may be proven by a higher content of terrigenous silica, $\mathrm{Na}, \mathrm{K}$, and $\mathrm{Mg}$ as compared to $\mathrm{Ju}_{\mathrm{IVI}}$ (Table 1; Figs. 7 and 8). For comparison, the surface organic sediment occurring in the marginal parts of the kettle hole (profile $\mathrm{Ju}_{\mathrm{III}}$ ), with the strongest effect of slope denudation, had a significantly higher content of 
terrigenous silica, $\mathrm{K}, \mathrm{Mg}, \mathrm{Pb}$, and $\mathrm{Zn}$ (Fig. 3). For this relatively thin $(0.35 \mathrm{~m})$ layer of sediments, a considerable reduction in $\mathrm{pH}$ values (to $<4$ ) towards the top uppermost layer was observed, which together with the presence of Sphagnum (particularly on the surface of the peat bog in its marginal part; Fig. 4) can indicate a transition towards ombrotrophy. It can be assumed that the likely cause of this phenomenon could be the exposure of the ground around the kettle hole (probably through deforestation), which intensified the water erosion in the drainage basin and resulted in an increased supply of acidic soil organic matter. No supply of groundwater and a relatively large inflow of matter from the catchment area obviously contribute to changes in the ecological conditions of the kettle hole. It should be noted, however, that a small area and location in the agricultural landscape prevent the development into a typical raised bog (Timmerman and Succow, 2001; Tobolski, 2003). Certain corresponding events were documented in the sediments of a peat bog in Tuchola Forest by Lamentowicz et al. (2007). According to the results of palynological analysis, the beginning of intensive agricultural land-use in the catchment area was recorded in sediments of $\mathrm{Ju}_{1}$ and $\mathrm{Ju}_{\| \mid}$at a depth of ca. 0.30 and $0.50 \mathrm{~m}$, respectively (Fig. 4). Pollen grains of synanthropic plants were found in the pollen spectra, i.e. cereals including Cerealia type and Secale cereale as well as Centaurea cyanus, Plantago lanceolata, Rumex, Artemisia and Chenopodiaceae. Sediments collected from the middle part of the depth range of $\mathrm{L} P A Z \mathrm{Ju}_{1-6}(0.25 \mathrm{~m})$ were AMS radiocarbon dated at $360 \pm 40$ BP; GDA-2400. After calibration, performed in the OxCal 4.2 application, the averaged date was determined as $1543 \mathrm{yr} A D$. At that time, those were arable lands, first controlled by the Teutonic Order, and then governed by the administration of the Ducal and East Prussia. The comparison of profiles $\mathrm{Ju}_{\mathrm{I}}$ and $\mathrm{Ju}_{\mathrm{II}}$ with other data from northeastern Poland (Wacnik, 2009, 2012) showed that profile $\mathrm{Ju}_{1}$ did not present a complete picture of the economic changes in this area. Most likely, a hiatus occurred in the Subatlantic record at a depth of $0.30 \mathrm{~m}$. The pollen record in the roof part of the surface sample was characterized by local encroachment of birch on the present-day area of the kettle hole studied.

The analysis of macroremains in the upper part of the sediments $(0.0-0.10 \mathrm{~m})$ of profile $\mathrm{Ju}$, showed the presence of numerous achenes of Betula sc. Albae and Carex elata as well as seeds of Comarum palustre (Fig. 5). This corresponded to a contemporarily developed tall-sedge community (Caricion elatae) with numerous birch trees in the vicinity. A very similar record is found in the uppermost layer from profile $\mathrm{Ju}_{1}$, where Betula pollen represents over $90 \%$ of all sporomorphs, while herbaceous plants were represented mostly by sedges (Cyperaceae pollen). It should be noted, however, that the analysis of macroremains was conducted only in the sediments from the central part of the peat bog $\left(\mathrm{Ju}_{1}\right)$, where Sphagnum succession has not yet been observed.

It appears that slope processes occurring in the drainage basin resulted in the formation of colluvial deposits (agricultural diamicton - Sinkiewicz, 1998; Frielinghaus and Vahrson, 1998), which are up to several dozen centimetres thick and cover a sequence of biogenic sediments (fossil soils; profiles $A$ and C, Figs. 2 and 3). This showed the existence of a larger (compared to its current size) water body, transformed mostly by anthropogenic denudation.

The extent and intensity of the catchment land use was also reflected in the $\mathrm{pH}$ of colluvial deposits (Fig. 3). In the case of long-term agricultural use (profile A), the acid reaction of the deposits can be attributed to the properties of initial surface soil horizons formed before the slope processes were activated within the top uppermost parts of the slopes (Smolska, 2005; Podlasiński, 2013; Karasiewicz et al., 2014a; Świtoniak, 2015). Significant accumulation of organic matter may act as the second factor responsible for acidification (Markiewicz et al., 2015). Neutral and slightly alkaline reactions (profile D) can be accounted for by the inflow of material from the zone with the most severe erosion processes, where carbonate-rich, parent rock soils are exposed (Świtoniak, 2014; Świtoniak et al., 2016). The effect of soil liming associated with afforestation of this part of the drainage basin also cannot be excluded.

\section{CONCLUSIONS}

Vertical diversification of the sedimentological and geochemical properties of the deposits in the kettle hole studied largely corresponded to environmental changes reconstructed through palaeobotanical studies. The geochemical record has been preserved in the bottom and slope sediments of the kettle hole as a result of both natural (e.g., climate changes, hydrographic conditions, vegetation cover) and anthropogenic processes (land use) occurring over the last several thousand years. This study showed that despite the small size of the kettle hole, its deposits have archived local and supralocal palaeoenvironmental changes.

Based on the results obtained it was possible to identify several postglacial stages reflecting the history of palaeoenvironmental changes in the kettle hole and the surrounding area. The first important stage consisted in the melting of a dead-ice block in permafrost conditions, followed by the stage of a small, late glacial lake, the sediments of which were deposited beneath the pollen-free layer. The presence of this layer provides evidence for the changing hydrological conditions, which resulted in a stratigraphic gap covering several thousand years (from the Preboreal to the Middle Atlantic), and consequently a temporary disappearance of the water body. In the subsequent stage, limnic conditions dominated again (mineral-organic gyttja), followed by telmatic conditions after the lake basin was filled with sediments (coarse detrital gyttja). This led to the development of a peat bog (sedge and sedge-moss peat deposits). These deposits contain a record of water-level fluctuations during the Subboreal and Subatlantic wet periods, and from the Middle Ages - a strong human impact. In this context, the reduction in the bottom surface of the kettle hole studied as a result of natural and anthropogenic denudation, as well as the strong acidification of the habitat, which resulted in Sphagnum succession, appear particularly important.

The authors hope that their research will contribute to a comprehensive reconstruction of the postglacial development of the Polish Lowland, and the results may be used in comparative studies.

Acknowledgements. We wish to thank O. Juschus and J. Forysiak for their valuable suggestions that improved the quality of this paper. Funding support for this research was provided by the Polish Ministry of Science and Higher Education (grant no. N N306 282935). 


\section{REFERENCES}

Apolinarska, K., Woszczyk, M., Obremska, M., 2012. Late Weichselian and Holocene palaeoenvironmental changes in northern Poland based on the Lake Skrzynka record. Boreas, 41: 292-307.

Bałaga, K., Chodorowski, J., 2006. Pollen analysis from fossi podzol soils within a dune at Kaczórki (Middle Roztocze, Poland). Acta Palaeobotanica, 46: 245-254.

Berglund, B.E., Ralska-Jasiewiczowa, M., 1986. Pollen analysis and pollen diagrams. In: Handbook of Holocene Palaeoecology and Palaeohydrology (ed. B.E. Berglund): 455-496. John Wiley and Sons, Chichester.

Bilotta, G.S., Brazier, R.E., Haygarth, P.M., 2007. Processes affecting transfer of sediment and colloids, with erosion. Hydrological Process, 21: 135-139.

Blott, S.J., Pye, K., 2001. Gradistat: a grain size distribution and statistics package for the analysis of unconsolidated sediments. Earth Surface Processes and Landforms, 26: 1237-1248.

Błaszkiewicz, M., 2008. Wytapianie się pogrzebanych brył martwego lodu w późnym glacjale i wczesnym holocenie a zdarzenia ekstremalne (in Polish). Landform Analysis, 8: 9-12.

Błaszkiewicz, M., 2011. Timing of the final disappearance of permafrost in the central European Lowland, as reconstructed from the evolution of lakes in N Poland. Geological Quarterly, 55 (4): 361-374.

Borówka, R.K., 1992. The pattern and magnitude of denudation in intraplateau sedimentary basins during the Late Vistulian and Holocene (in Polish with English summary). Seria Geografia, 54. Wydawnictwo UAM, Poznań.

Bronk Ramsey, C., 2009. Bayesian analysis of radiocarbon dates. Radiocarbon, 51: 337-360.

Cohen, A.S., 2003. Paleolimnology: the History and Evolution of Lake Systems. Oxford University Press, New York.

Cooper, C.M., Knight, S.S., 1990. Nutrient trapping efficiency of a small sediment detention reservoir. Agricultural Water Management, 18: 149-158.

Drexler, J.Z., Bedford, B.L., Scognamiglio, R., Siegel, D.I., 1999. Fine-scale characteristics of groundwater flow in a peatland. Hydrological Processes, 13: 1341-1359.

Dyakowska, J., 1959. Podręcznik palynologii (in Polish). Metody i problemy. Wyd. Geol., Warszawa.

Folk, R.L., Ward, W.C., 1957. Brazos River bar: a study in the significance of grain size parameters. Journal of Sedimentary Petrology, 27 : 3-26.

Forysiak, J., 2015. Geomorphological diversity of peatland basins in the Łódź region and its significance for the accumulation of biogenic sediments. Bulletin of Geography, Physical Geography Series, 8: 59-70

Franz, S.O., Schwark, L., Bruchmann, C., Scharf, B., Klingel, R., Van Alstine, J.D., Cagatay, N., Ulgen, U.B., 2006. Results from a multi-disciplinary sedimentary pilot study of tectonic Lake Iznik (NW Turkey) - geochemistry and paleolimnology of the recent past. Journal of Paleolimnology, 35: 715-736.

Fraser, C.J., Roulet, N.T., Lafleur, P.M., 2001. Groundwater flow patterns in a large peatland. Journal of Hydrology, 246: 142-154.

Frielinghaus, M., Vahrson, W.G., 1998. Soil translocation by water erosion from agricultural cropland into wet depressions (morainic kettle holes). Soil and Tillage Research, 46: 23-30.

Gamrat, W.W., Andrzejewski, L., Krześlak, I., 2014. Postglacjalne zmiany środowiska przyrodniczego na Wysoczyźnie Dobrzyńskiej zapisane na profilu osadów biogenicznych w Piotrkowie (in Polish). Landform Analysis, 25: 3-11.

Gorham, E., Rochefort, L., 2003. Peatland restoration: a brief assessment with special reference to Sphagnum bogs. Wetlands Ecology and Management, 11: 109-119.

Hirsch, F., Schneider, A., Nicolay, A., Błaszkiewicz, M., Kordowski, J., Noryśkiewicz, A.M., Tyszkowski, S., Raab, A., Raab, T., 2015. Late Quaternary landscape development at the margin of the Pomeranian phase (MIS 2) near Lake Wygonin (Northern Poland). Catena, 124: 28-44.
IUSS Working Group WRB, 2015. World Reference Base for Soil Resources 2014. International Soil Classification System for Naming Soils and Creating Legends for Soil Maps. World Soil Resources Reports No. 106. FAO, Rome.

Jäger, H., Achermann, M., Waroszewski, J., Kabała, C., Malkiewicz, M., Gärtner, H., Dahms, D., Krebs, R., Egli, M., 2015. Pre-alpine mire sediments as a mirror of erosion, soil formation and landscape evolution during the last $45 \mathrm{ka}$. Catena, 128: 63-79.

Kalettka, T., Rudat, C., 2006. Hydrogeomorphic types of glacially created kettle holes in North-East Germany. Limnologica, 36: $54-64$.

Karasiewicz, M.T., 2006a. Maximum range and layout of the marginal zone of the Vistulian ice sheet during the Pomeranian phase in the vicinity of lake Narie. Quaestiones Geographicae, 25A: 27-37.

Karasiewicz, M.T., 2006b. Morfogeneza obszaru w okolicy Moraga (in Polish). Dokumentacja Geograficzna, 32: 129-134.

Karasiewicz, M.T., Hulisz, P., Świtoniak, M. eds., 2012. Postglacjalna historia zagłębienia bezodpływowego w rezerwacie Retno (Pojezierze Brodnickie) (in Polish). Wydawnictwa Naukowe UMK, Toruń: 1-161.

Karasiewicz, M.T., Hulisz, P., Świtoniak, M., 2014a. Wpływ procesów denudacji na właściwości osadów wypełniających zagłębienia między krętymi wałami z erozji wód subglacjalnych w okolicy Zbójna (Pojezierze Dobrzyńskie) (in Polish). Landform Analysis, 25: 29-42.

Karasiewicz, M.T., Hulisz, P., Noryśkiewicz, A.M., Krześlak. I., Świtoniak, M., 2014b. The record of hydroclimatic changes in the sediments of a kettle-hole in a young glacial landscape (north-central Poland). Quaternary International, 328-329: 264-276

Kleeberg, A., Neyen, M., Schkade, U.-K., Kalettka, T., Lischeid, G., 2015. Sediment cores from kettle holes in NE associated phosphorus, from intensively farmed grasslands. Environmental Science and Pollution Research, 23: 7409-7424.

Kochanowska, R., Pieńkowski, P., Podlasiński, M., 1998. Characteristics of intrafield water holes in Western Pomerania in relation to differention of the Young-glacial landscape and human impact. Journal of Water Land Development, 2: 85-101.

Kowalewski, G., 2014. Alogeniczne i autogeniczne składowe zarastania jezior: hipoteza wahań poziomu wody (in Polish). Studia Limnologica et Telmatica, Monographiae, I: 1-191.

Krześlak, I., Andrzejewski, L., Gamrat, W., Kupniewska, A., 2014. Późnoglacjalna i holoceńska ewolucja torfowiska w Dzikowie (Kotlina Toruńska) w świetle badań paleogeograficznych (in Polish). Landform Analysis, 25: 95-103.

Kupryjanowicz, M., Filbrandt-Czaja, A., Noryśkiewicz, A.M., Noryśkiewicz, B., Nalepka, D., 2004. Tilia L - Lime. In: Late Glacial and Holocene history of vegetation in Poland based on isopollen maps (eds. M. Ralska-Jasiewiczowa, M. Latałowa, K. Wasylikowa, K. Tobolski, E. Madeyska, H.E.Jr. Wright and Ch. Turner): 217-224. W. Szafer Institute of Botany, Polish Academy of Sciences, Kraków.

Küster, M., Ruchhöft, F., Lorenz, S., Janke, W., 2011 Geoarchaeological evidence of Holocene human impact and soil erosion on a till plain in Vorpommern (Kühlenhagen, NE-Germany). Quaternary Science Journal, 60: 455-463.

Lamentowicz, M., Tobolski, K., Mitchell, E.A.D., 2007. Palaeoecological evidence for anthropogenic acidification of a kettlehole peatland in northern Poland. The Holocene, 17: 1185-1196.

Lamentowicz, M., Obremska, M., Mitchell, E.A.D., 2008. Autogenic succession, land-use change, and climatic influences on the Holocene development of a kettle hole mire in Northern Poland. Review of Palaeobotany and Palynology, 151: 21-40.

Lamentowicz, M., Forysiak, J., Balwierz, Z., Kloss, M., Kittel, P., Żurek, S., Pawlyta, J., 2009. Multiproxy study of anthropogenic and climatic changes in the last two millennia from a small mire in central Poland. Hydrobiologia, 631: 213-230. 
Major, M., 2009. Charakter i funkcjonowanie zagłębień bezodpływowych w krajobrazie strefy młodoglacjalnej (Pomorze Zachodnie, górna Parsęta) (in Polish). Wydawnictwo Poznańskiego TPN, Poznań: 1-176.

Malkiewicz, M., Waroszewski, J., Bojko, O., Egli, M., Kabala, C., 2016. Holocene vegetation history and soil development reflected in the lake sediments of the Karkonosze Mountains (Poland). The Holocene, 26: 890-905.

Markiewicz, M., Mendyk, Ł., Gonet, S.S., 2015. Soil organic matter status in agricultural soil sequence of former shoreline of disappearing Sumowskie Lakes, North-Eastern Poland. Polish Journal of Soil Science, 48: 65-78.

Mendyk, Ł., Markiewicz, M., Bednarek, R., Świtoniak, M., Gamrat, W.W., Krześlak, I., Sykuła, M., Gersztyn, L., Kupniewska, A., 2015. Environmental changes of a shallow kettle lake catchment in a young glacial landscape (Sumowskie Lake catchment), North-Central Poland. Quaternary International, 413: 116-131.

Nalepka, D., Walanus, A., 2003. Data processing in pollen analysis. Acta Palaeobotanica, 43: 125-134.

Niewiarowski, W., 1989. Wahania poziomu jezior w późnym glacjale i holocenie na przykładzie jezior Pojezierza Brodnickiego (in Polish). Studia i Materiały Oceanologiczne, 56: 277-288.

Niewiarowski, W. ed., 1995. Zarys zmian środowiska geograficznego okolic Biskupina pod wpływem czynników naturalnych i antropogenicznych w późnym glacjale i holocenie (in Polish). Oficyna Wydawnicza Turpress, Toruń.

Noryśkiewicz, B., 1987. History of vegetation during the Late-Glacial and Holocene in Brodnica Lake District in the light of pollen analysis of Lake Strażym deposists. Acta Palaeobotanica, 27: 283-304.

Noryśkiewicz, A.M., 2006. Historia cisa w okolicy Wierzchlasu w świetle analizy pyłkowej (in Polish with English summary). Wydawnictwo Naukowe Uniwersytetu Mikołaja Kopernika, Toruń

Noryśkiewicz, A.M., 2013. Vegetation and settlenent history of the Chełmno Land in Late Holocene. Palynological study (in Polish with English summary). Wydawnictwo Naukowe Uniwersytetu Mikołaja Kopernika, Toruń

Podlasińska, J., 2012. Zróżnicowanie i chemizm osadów małych zbiorników wodnych w krajobrazie młodoglacjalnym (in Polish). Zachodniopomorski Uniwersytet Technologiczny, Szczecin.

Podlasiński, M., 2013. Wpływ denudacji antropogenicznej na zróżnicowanie pokrywy glebowej i jej przestrzenna strukture w rolniczym krajobrazie morenowym (in Polish). Wydawnictwo Uczelniane Zachodniopomorskiego Uniwersytetu Technologicznego w Szczecinie.

Ralska-Jasiewiczowa, M., Goslar, T., Madeyska, T., Starkel, L. eds., 1998. Lake Gościaż, Central Poland. A Monographic Study (Part 1). W. Szafer Institute of Botany, Kraków.

Roszkówna, L., 1955. Endmorains of the western Mazurian lake country (in Polish with English summary). Studia Societatis Scientiarum Toruniensis, 2: 35-95.

Sinkiewicz, M., 1998. Rozwój denudacji antropogenicznej w środkowej części Polski Północnej (in Polish). Wydawnictwo Uniwersytetu Mikołaja Kopernika, Toruń: 1-103.

Smolska, E., 2005. Znaczenie spłukiwania w modelowaniu stoków młodoglacjalnych (na przykładzie Pojezierza Suwalskiego) (in Polish). WGiSR UW Warszawa: 1-146.

Stachowicz-Rybka, R., 2011. Flora and vegetation changes on the basis of plant macroremains analysis from an early Pleistocene lake of the Augustów Plain, NE Poland. Acta Palaeobotanica, 51: 39-104.

Starkel, L., Pazdur, A., Pazdur, M.F., Wicik, B., Więckowski, K. 1998. Lake-level changes and palaeohydrological reconstructions during the Holocene. In: Lake Gościąż, Central Poland, a Monographic Study, Part 1 (eds. M. Ralska-Jasiewiczowa, T. Goslar, T. Madeyska and L. Starkel): 225-229. Instytut Botaniki PAN, Kraków.

Stockmarr, J., 1971. Tablets with spores of absolute pollen analysis. Pollen et Spores, 13: 615-621.

Szoszkiewicz, K., Jusik, Sz., Zgoła, T., 2010. Guide for identification of macrophytes for assessment of the ecological state of freshwaters (in Polish with English summary). Biblioteka Monitoringu Środowiska, Warszawa.

Szwarczewski, P., 2008. Uwagi o wieku późnoglacjalnych i holoceńskich osadów organicznych i tempie ich akumulacji na przykładzie okolic Sejn (in Polish). Polish Academy of Science Kraków, Geobotanical Guidebooks, 30: 183-194.

Szwarczewski, P., Kupryjanowicz, M., 2008. Etapy rozwoju zagłębień bezodpływowych w okolicach Sejn (in Polish). Polish Academy of Science Kraków, Geobotanical Guidebooks, 30 195-205.

Środoń, A., 1991. Lipa w minionych krajobrazach Polski (in Polish). In: Lipy „Tilia cordata Mill.”, „Tilia platyphyllos Scop.” (ed. W. Bałaga): 9-19. Arcadia, Kórnik-Poznań

Świtoniak, M., 2014. Use of soil profile truncation to estimate influence of accelerated erosion on soil cover transformation in young morainic landscapes, North-Eastern Poland. Catena, 116: 173-184

Świtoniak, M., 2015. Issues relating to classification of colluvial soils in young morainic areas (Chełmno and Brodnica Lake District, northern Poland). Soil Science Annual, 66: 57-66.

Świtoniak, M., Mroczek, P., Bednarek, R., 2016. Luvisols or Cambisols? Micromorphological study of soil truncation in young morainic landscapes - case study: Brodnica and Chełmno Lake Districts (North Poland). Catena, 137: 583-595.

Timmermann, T., Succow, M., 2001. Kesselmoore. In: Land schafts-ökologische Moorkunde. 2. Aufl (eds. M. Succow and H. Joosten): 379-390. E.Schweizerbart, Stuttgart.

Tobolski, K., 2003. Torfowiska na przykładzie Ziemi Świeckiej (in Polish). TPDW, Świecie.

Twardy, J., Żurek, S., Forysiak, J. eds., 2010. Torfowisko Żabieniec, warunki naturalne, rozwój i zapis zmian paleoekologicznych w jego osadach (in Polish). Bogucki Wydawnictwo Naukowe, Poznań.

Van Loon, A.J., Błaszkiewicz, M., Degórski, M., 2012. The role of permafrost in shaping the Late Glacial relief of northern Poland. Netherlands Journal of Geosciences, 91: 223-231.

Wacnik, A., 2009. Galindowie i Krzyżacy - oddziaływania na lokalna roślinność w rejonie Miłek i Staświn (Kraina Wielkich Jezior Mazurskich, Północno-wschodnia Polska) (in Polish). Wiadomości Botaniczne, 53: 21-34.

Wacnik, A., 2012. Vegetation changes caused by agricultural societatis in the Great Mazurian Lake District. Acta Palaeobotanica, 52: 59-104.

Wieckowski, K., 1989. A new method of coring in deep lakes with rod operated samplers. Boreas, 18: 357-358.

Wysota, W., Noryśkiewicz, B., 2011. Geomorphology and vegetation history of the Rypienica channel, the Dobrzyń Lakeland, North Poland. Bulletin of Geography, Physical Geography Series, 4: 71-88. 